\title{
Volcano stratigraphy and physical characterization of the San Mateo Pomez Unit, Cerritos Member: Temascalcingo Volcano, Central Mexico
}

\author{
Dario Pedrazzi $^{\mathrm{a}, \mathrm{b}}$, , Gerardo J. Aguirre-Díaz $^{\mathrm{b}}$, Iván Sunyé-Puchol ${ }^{\mathrm{b}}$, Laura Becerril ${ }^{\mathrm{a}, \mathrm{c}}$, Daniel P. Miggins ${ }^{\mathrm{d}}$ \\ a ICTJA, CSIC, Group of Volcanology, SIMGEO UB-CSIC, Institute of Earth Sciences Jaume Almera, Lluis Sole i Sabaris s/n, 08028 Barcelona, Spain \\ ${ }^{\mathrm{b}}$ Centro de Geociencias, Universidad Nacional Autónoma de México, Campus Juriquilla, 76230 Querétaro, QRO, Mexico \\ c Servicio Nacional de Geología y Minería, SERNAGEOMIN, Avd. Santa María, 0104 - Providencia, Santiago de Chile, Chile \\ ${ }^{\mathrm{d}}$ College of Earth, Ocean and Atmospheric Sciences, Oregon State University, 104 CEOAS Administration Building, 101 SW 26 th St, Corvallis, OR 97331, United States of \\ America
}

\section{A R T I C L E I N F O}

\section{Article history:}

Received 19 June 2018

Received in revised form 4 October 2018

Accepted 8 October 2018

Available online xxx

Keywords:

trans-Mexican Volcanic Belt

Acambay graben

Debris avalanche

Subplinian eruption

VORIS 2.1.1

\begin{abstract}
A B S T R A C T
The Temascalcingo volcano is a dacitic stratovolcano located at the eastern part of the Acambay graben, a tectonic basin in the central sector of the Trans-Mexican Volcanic Belt (TMVB), which is an active, mostly calc-alkaline volcanic arc that crosses Mexico from the Pacific Ocean to the Gulf of Mexico. This study characterises the explosive activity of the San Mateo Pumice eruption that is the most recent and largest paroxysmal episode of this volcano and the last unit of the Cerritos Member. Indeed, this eruption is associated with an undated debris avalanche event consisting of a major sector collapse developed on the western flank of the volcano.

Stratigraphic data suggest a highly explosive eruption that generated a relatively thick (up to $10 \mathrm{~m}$ ) and widespread pumice fallout deposit, trending to the NE, and an aerial distribution of at least $100 \mathrm{~km}^{2}$. This subplinian type eruption of VEI 4 lasted about $9 \mathrm{~h}$ and produced a plume height up to $12 \mathrm{~km}$ above the vent (i.e., $\sim 14 \mathrm{~km}$ above sea level). This type of explosive eruption is relatively common in the TMVB, so a comprehensive geological study, with the corresponding numerical simulations like the one that was carried out, contributes to the understanding of the explosive volcanism of modest size stratovolcanoes that are common in the TMVB.
\end{abstract}

(C) 2018

\section{Introduction}

The Trans-Mexican Volcanic Belt (TMVB) includes stratovolcanoes (Fig. 1a), some well-known, such as Popocatépetl, Iztaccihuatl, Nevado de Toluca and Colima (Demant, 1978; Siebe et al., 2006), and many others of more modest dimensions that are not as well-known e.g., Tequila, San Juan, Sangangüey, Cerro Culiacán, Cerro Grande, El Zamorano, La Joya, Palo Huérfano, Jocotitlán, Altamirano, and Temascalcingo (Nelson, 1980; Nelson and Livieres, 1986; Nelson and Hegre, 1990; Siebe et al., 1992; Hasenaka, 1994; Wallace and Carmichael, 1994; Valdéz-Moreno et al., 1998; Verma and Carrasco-Núñez, 2003).

Temascalcingo volcano (TV) is located within the Acambay graben (Fig. 1b,c), in the states of México and Michoacán, Mexico (Suter et al., 1995a, 1995b; Aguirre-Díaz, 1996). The only published scientific work about TV was carried out by Roldán-Quintana et al. (2011), who referred to the general geological characteristics of the volcano, focusing on the description of an undated sector collapse event. Recent studies mentioning volcanoes in the Acambay graben deal with structural geology, paleoseismicity, and detailed local

\footnotetext{
* Corresponding author at: ICTJA, CSIC, Group of Volcanology, SIMGEO UB-CSIC, Institute of Earth Sciences Jaume Almera, Lluis Sole i Sabaris s/n, 08028 Barcelona, Spain.

Email address: dpedrazzi@ictja.csic.es (D. Pedrazzi)
}

stratigraphy of trenches with palaeoseismological purposes (Ortuño et al., 2012; Lacan et al., 2013; Sunyé-Puchol et al., 2012, 2015; Langridge et al., 2013; Ortuño et al., 2015; Lacan et al., 2017; Ortuño et al., 2018; Lacan et al., 2018).

The present study uses a volcanological-oriented approach to better understand the evolution of TV and its eruptive history, focussing on the San Mateo Pumice (SMP) eruption. The SMP eruption is one of the greatest paroxysmal episodes of TV, with pumice deposits mainly exposed at the northern and north-eastern flanks of the volcano and with thicknesses up to $2 \mathrm{~m}$ near the town of Acambay (Fig. 1b and c). The SMP eruption was associated with the undated debris avalanche event reported in Roldán-Quintana et al. (2011), consisting of a major sector collapse developed on the western flank of the volcano, leaving a $6.5 \times 3.5 \mathrm{~km}$ horseshoe shaped scar (Fig. 1c). The avalanche deposit is found at the western side of TV (Fig. 1c), with outcrops up to $6 \mathrm{~km}$ from the volcano. It includes hummocks up to $100 \mathrm{~m}$ high and covers an area of $23 \mathrm{~km}^{2}$, representing a minimum estimated volume of $0.8 \mathrm{~km}^{3}$. A PDC, called the Magdalena Flow, was also associated with the avalanche. Roldán-Quintana et al. (2011) proposed that this sector collapse and blast event of TV was similar in style to that of Mount St. Helens' May 18th, 1980 eruption (e.g., Fisher, 1990; Druitt, 1992).

Volcanic sector collapse events are common within the TMVB (Capra and Macías, 2000). In the proximity of the Acambay graben, two other sector collapse avalanches are recognised: at Jocotitlán vol- 


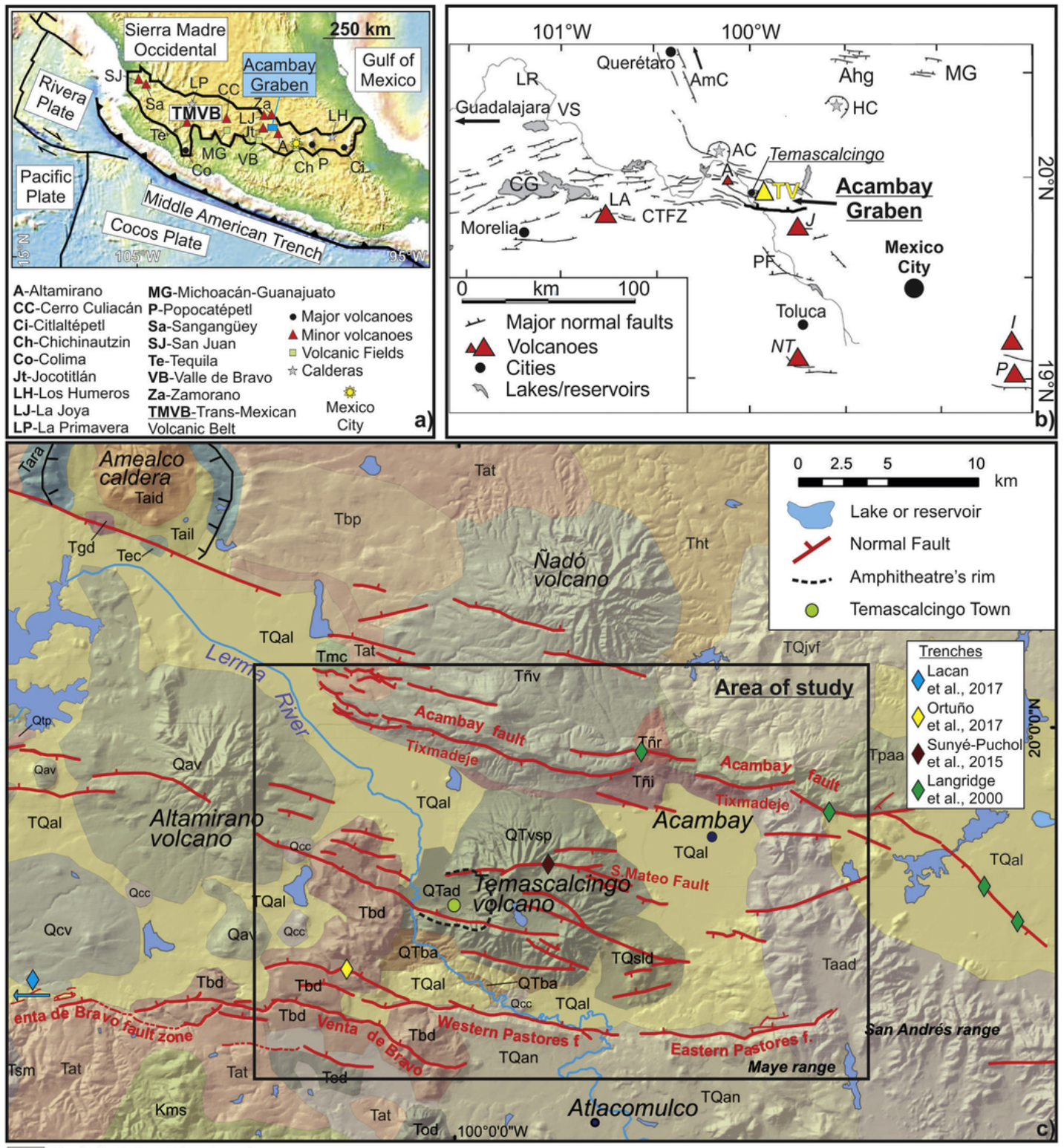

TQal Plio-Qt fluvio-lacustrine deposits.

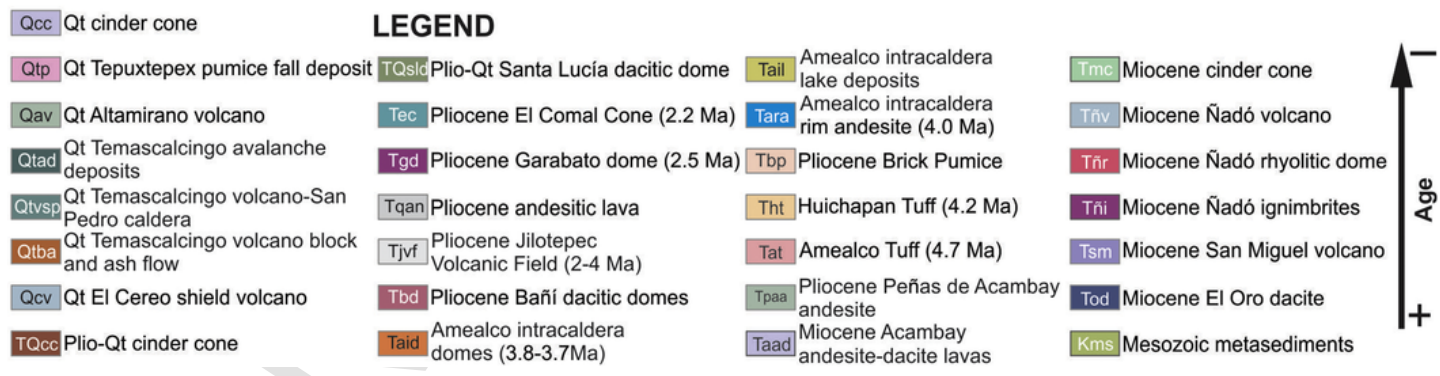

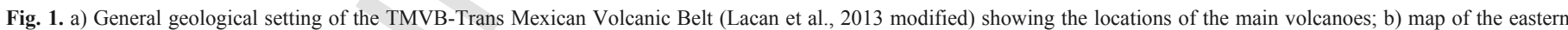

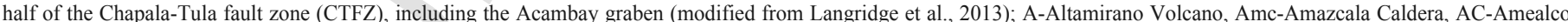

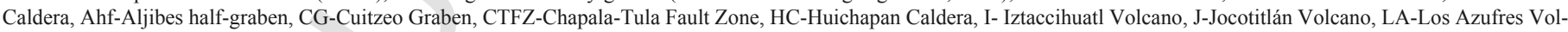

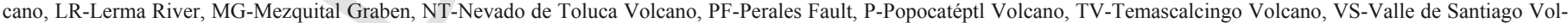
canic Field; c) simplified geologic map of the Acambay graben showing the main lithostratigraphic units and geomorphological fault traces (modified from Ortuño et al., 2015). 
cano (Siebe et al., 1992; Salinas and López-Blanco, 2010), and Nevado de Toluca volcano (Macías et al., 1997; Capra and Macías, 2000). Further away, they are reported at Nevado de Colima and Fuego (Robin et al., 1987, 1990; Luhr and Prestegaard, 1988; Stoopes and Sheridan, 1992; Komorowski et al., 1994, 1997), Popocatepetl (Robin and Boudal, 1987; Siebe et al., 1995b; Lozano-Velazquez and Carrasco-Núñez, 1997), Las Derrumbadas (Siebe et al., 1995a) and Pico de Orizaba (Carrasco-Núñez and Gomez-Tuena, 1997; Carrasco-Núñez et al., 1993; Hoskuldsson and Robin, 1993).

A detailed field survey of the SMP was carried out, with the aim of obtaining physical eruptive parameters, in order to understand the dynamics of the eruption by correlating the SMP deposits with the sector collapse. Radiocarbon and radiogenic dating were also carried out to better constrain the age of the eruption. In addition, numerical simulations were performed to better constrain the parameters involved in the SMP eruption and to depict the most probable eruptive scenario within the Acambay graben.

\section{Geological setting and general characteristics of Temascalcingo volcano}

The Acambay graben is located within the central part of the TMVB. This is an active, mostly calc-alkaline volcanic arc that crosses Mexico from the Pacific Ocean to the Gulf of Mexico (Demant, 1978; De Cserna, 1989; Aguirre-Díaz et al., 1998; Ferrari et al., 2012; Fig. 1a). This volcanic arc is associated with the subduction of the Cocos and Rivera plates beneath the North America plate (Nixon, 1982; Suárez and Singh, 1986; Fig. 1a). Due to the plate boundary readjustments since the Miocene, the TMVB was superimposed on the NNW-trending Sierra Madre Occidental volcanic province of Mexico (Ferrari et al., 1999, 2012; Cerca Martinez et al., 2000; Fig. 1a).

Different types of volcanism characterise the TMVB (Aguirre-Díaz et al., 1998, 2006). These include monogenetic basaltic fields, such as the Michoacán-Guanajuato, Chichinautzin, and Valle de Bravo (Hasenaka and Carmichael, 1985; Siebe et al., 2005; Aguirre-Díaz et al., 2006; Fig. 1a); large andesitic stratovolcanoes such as Popocatépetl, Citlaltépetl, and Colima (Siebe et al., 1996; Carrasco-Núñez, 1999; Luhr and Carmichael, 1980; Fig. 1a), mid-size stratovolcanoes, such as Jocototitlán, Altamirano, and Temascalcingo, the subject of this study (Fig. 1a and c); and rhyolitic volcanism with large silicic calderas, such as La Primavera, Amealco, Amazcala, Huichapan, and Los Humeros (Mahood, 1980; Ferriz and Mahood, 1987; Aguirre-Díaz, 1996; Carrasco-Nuñez et al., 2017; Aguirre-Díaz and López-Martínez, 2001; Aguirre-Díaz and López-Martínez, 2009; Fig. 1a).

The central part of the TMVB is influenced by the Chapala-Tula Fault Zone (Johnson and Harrison, 1990; CTFZ-Fig. 1b) and comprises a complex mosaic of horsts and grabens that extend from Guadalajara City to Mexico City (Aguirre-Díaz, 1996; Aguirre-Díaz et al., 1998). The westernmost part of this area is characterised by two tectonic structures: the Cuitzeo (CG) and the Acambay grabens (Suter et al., 1995a, 2001; Fig. 1b). The latter has been the subject of numerous neotectonic studies (Suter et al., 1991, 1992, 1995a, 1995b, 2001; Ramírez-Herrera, 1994, 1998; Langridge et al., 2000, 2013; Aguirre-Díaz et al., 2005; Sunyé-Puchol et al., 2015; Ortuño et al., 2015; Lacan et al., 2017). The Acambay graben, which is up to $80 \mathrm{~km}$ long and $15-38 \mathrm{~km}$ wide, is defined by four major E-W striking normal faults: the Venta de Bravo and Pastores faults in the south and the Acambay-Tixmadejé and Epitacio Huerta faults in the north (Suter et al., 1992, 1995a; Fig. 1c). These faults affect Neogene and Quaternary deposits of scoria cones and domes, lava bodies of basaltic, an- desitic, and rhyolitic composition, as well as pyroclastic deposits (Suter et al., 1991; Aguirre-Díaz, 1995, 1996; Aguirre-Díaz and McDowell, 2000; Garduño-Monroy et al., 2009; Ortuño et al., 2015). Volcanic rocks of the TMVB that surround the Acambay graben are Miocene to Quaternary in age (Aguirre-Díaz, 1996; Aguirre-Díaz et al., 2000) (Fig. 1c), and form the footwall blocks of the graben and the basement of the hanging wall (Sánchez-Rubio, 1984; Aguirre-Díaz, 1993, 1996; Aguirre-Díaz et al., 2000).

The TV (Fig. 1c) is an andesitic-dacitic stratovolcano located in the eastern part of the Acambay graben, in the municipalities of Temascalcingo and Acambay (northwest portion of the State of Mexico). The volcano rises $800 \mathrm{~m}$ from its base, making it one of the highest parts of the region, with peaks of $3000-3100 \mathrm{~m}$ above sea level. The TV was affected by the active Acambay graben fault system and is cut by four major ESE-WNW faults (Fig. 1c), of which the best studied is the San Mateo fault (Sunyé-Puchol et al., 2015). The fault system is active as evidenced by the 1912 Acambay earthquake (Langridge et al., 2000) and current studies on the Temascalcingo fault are ongoing (Ortuño et al., 2018; Lacan et al., 2018). The volcano includes a rectangular summit caldera, $2 \times 3 \mathrm{~km}$, with its largest dimension oriented E-W (Aguirre-Díaz et al., 2015; Fig. 1c).

Mainly high aspect ratio dacitic lavas form the TV along with block and ash flow deposits in addition to subordinate pumice fall deposits and ignimbrites (Aguirre-Díaz et al., 2015). At the western side of the volcano, Bañí Domes (Pliocene) of dacitic composition, with flat tops and steep edges, occupy the central part of the Acambay graben (Tbd; Fig. 1c). To the south and southeast, Pliocene mafic volcanic rocks of uncertain origin are observed (Tqan; Fig. 1c). To the east, there is the remarkably flat valley of Acambay and the Santa Lucía high-standing dome and associated debris avalanche deposit (Tqsid; Fig. 1c). To the north, volcanic rocks are exposed in the master fault of the Acambay graben, with predominantly andesitic lavas of the hefty Nadó volcano (Tnv; Fig. 1c), which is undated but is older than 4.7 Ma ignimbrites of the Amealco caldera (Tat; Fig. 1c) (Aguirre-Díaz, 1996; Aguirre-Díaz and McDowell, 2000).

\section{Methods}

A preliminary study and interpretation of 1:5000 scale orthophotos was carried out to obtain a complete overview of the area and to identify possible outcrops of interest. Subsequent field mapping was undertaken at 1:10,000 scale covering an area of about $120 \mathrm{~km}^{2}$ to reconstruct the stratigraphy of the SMP deposit and its relationships with other units. Stratigraphic criteria included grading, colour and sorting, the component content (juvenile and lithic fragments) and primary volcano-sedimentary structures. Nomenclature used in the text for bed thickness, grain size and sorting of the pyroclastic deposits follows that proposed by Sohn and Chough (1989). Classification for primary volcanoclastic deposits follows White and Houghton (2006). Nomenclature for volcanic stratigraphy is based on Martí et al. (2018). 35 stratigraphic sections were measured and used to document the geometry of the deposits and their component proportions (Table 1) but stratigraphic details are only reported here for 15 (Fig. 2) since they are representative of the whole deposit and its facies variations.

Maximum clast sizes (referring to the first climax phase of the eruption as pointed out by the red arrows at Outcrop 9 in Fig. 2) were measured based on the geometric mean of the three axes of the five largest clasts sampled over an area of $0.5 \mathrm{~m}^{2}$. From this data two isopleth maps (juvenile pumices and dacitic lava lithics) were constructed. Thicknesses of the units were measured to create an isopach map, although most of the sections have eroded tops. All georefer- 
Table 1

Thickness, juvenile and lithic maximum clast sizes. Bold entries are those for which stratigraphic columns are given in Fig. 2.

\begin{tabular}{|c|c|c|c|c|c|}
\hline Outcrop & X UTM 14Q & Y UTM 14Q & Thickness & Juveniles & Lithics \\
\hline & (m) E & (m) $\mathrm{N}$ & $(\mathrm{cm})$ & $(\mathrm{cm})$ & $(\mathrm{cm})$ \\
\hline 1 & 404,520 & $2,203,301$ & 450 & 3.36 & 2 \\
\hline 2 & 404,663 & $2,203,189$ & 200 & 2.42 & 1 \\
\hline 3 & 406,232 & $2,202,292$ & 100 & 2.36 & 3.64 \\
\hline 4 & 405,839 & $2,202,101$ & 270 & 2.3 & 3.61 \\
\hline 9 & 400,138 & $2,207,619$ & 1000 & 3.8 & 2 \\
\hline 10 & 400,187 & $2,207,338$ & 880 & 3.5 & 1.9 \\
\hline 11 & 400,551 & $2,207,367$ & 330 & 4.5 & 2.7 \\
\hline 16 & 404,337 & $2,204,327$ & 280 & 2.8 & 1.5 \\
\hline 17 & 401,224 & $2,205,924$ & 320 & 2.68 & 1.1 \\
\hline 20 & 402,213 & $2,206,367$ & 470 & 2 & 0.7 \\
\hline 22 & 406,576 & $2,209,492$ & 220 & 3.5 & 2.2 \\
\hline 26 & 405,656 & $2,208,034$ & 300 & 3.4 & 1.3 \\
\hline 27 & 404,461 & $2,207,931$ & 80 & 1.82 & 0.6 \\
\hline 28 & 404,616 & $2,207,888$ & 540 & 2.8 & 1 \\
\hline 29 & 404,612 & $2,208,507$ & 100 & 1.16 & 0.3 \\
\hline 30 & 404,337 & $2,208,472$ & 100 & 1.16 & 0.3 \\
\hline 31 & 404,173 & $2,208,246$ & 290 & 3.5 & 0.9 \\
\hline 32 & 404,896 & $2,208,724$ & 100 & 1.55 & 0.55 \\
\hline 33 & 405,227 & $2,209,351$ & 390 & 2.3 & 1 \\
\hline 36 & 403,178 & $2,208,490$ & 790 & 3.9 & 1.6 \\
\hline 39 & 410,439 & $2,209,193$ & 230 & 1.5 & 1 \\
\hline 40 & 410,390 & $2,208,791$ & 70 & 2 & 1 \\
\hline 43 & 405,087 & $2,203,160$ & 300 & 3.7 & 1 \\
\hline 44 & 412,099 & $2,199,390$ & 140 & 2.26 & 0.1 \\
\hline 46 & 412,495 & $2,202,538$ & 90 & 2.64 & 0.1 \\
\hline 47 & 413,847 & $2,201,762$ & 50 & 1.21 & 0.64 \\
\hline 49 & 408,000 & $2,210,413$ & 100 & 1 & 0.1 \\
\hline 52 & 398,768 & $2,209,410$ & 750 & 2.46 & 1.46 \\
\hline 53 & 398,109 & $2,209,208$ & 810 & 2.2 & 2.24 \\
\hline 54 & 391,838 & $2,202,869$ & 315 & 2.3 & 0.6 \\
\hline 55 & 392,142 & $2,204,151$ & 540 & 2 & 0.5 \\
\hline 57 & 393,635 & $2,212,575$ & 90 & 2.6 & 2 \\
\hline 59 & 394,282 & $2,210,520$ & 200 & 3.1 & 1.5 \\
\hline 60 & 394,891 & $2,208,431$ & 130 & 2 & 3 \\
\hline 61 & 395,713 & $2,209,289$ & 700 & 3.1 & 1.6 \\
\hline
\end{tabular}

enced data were managed and processed using the software Quantum Gis Las Palmas (open source-https://www.qgis.org/it/site/). To obtain volumetric data from the maps, we applied various methods such as exponential, power-law, and Weibull integration (Pyle, 1989; Bonadonna and Houghton, 2005; Bonadonna and Costa, 2012, 2013) using the AshCalc tool (Daggitt et al., 2014). The erupted mass was calculated from the deposit density in the field, obtained by weighting in situ a known volume of pumice clasts, plus intergranular porosity and matrix from the Temas-1 outcrop (Fig. 2).

The height of the volcanic plume and the wind speed at the time of the eruption was determined by the method of Carey and Sparks (1986). The peak mass eruption rate (MER) was calculated applying both the method of Wilson and Walker (1987) and of Mastin et al. (2009). The eruption duration was estimated based on the ratio between erupted mass (Weibull integration) and the MER value. Finally, the VEI (Newhall and Self, 1982), magnitude and intensity of the eruption (Pyle, 2000) the style of eruption (Pyle, 1989; Bonadonna and Costa, 2013) were estimated.

All parameters were used to simulate the SMP eruption and to better constrain the isopach map through the software VORIS 2.1.1 (Felpeto et al., 2007), an advection-diffusion model where the vertical mass distribution is computed using Suzuki's approximation (Suzuki, 1983). Different fallout scenario simulations were done in order to obtain (a) a future scenario using the parameters of a subplinian eruption and using the current winds; (b) a deposit mass distribution. In that sense, we refined and obtained the most accurate input parameters for the eruption. Wind data were obtained from the Uni- versity of Wyoming Department of Atmospheric Science sounding database (http://weather.uwyo.edu/upperair/sounding.html). Wind data for a complete year was averaged in order to obtain wind direction and intensity at different heights.

Geographical coordinates of relevant locations, as well as stratigraphic sections and sampling points, were recorded using a portable Garmin Dakota-20 GPS to a precision of about $3 \mathrm{~m}$. The reference zone used was the UTM projection Datum: D WGS 1984, Zone 14N.

A binocular microscope was used to determine the main petrographic and textural characteristics of the juvenile components, and to identify the mineralogy and general composition of the studied deposits. All the analyses were performed in the Physical Volcanology Laboratory of Centro de Geociencias, Universidad Nacional Autónoma de México, at Juriquilla-Querétaro (Mexico). The most representative levels of each stratigraphic unit were sampled and analysed (94 samples in total- see Fig. 2 and Supplementary Materials 1 and 2 for grain-size distribution and componentry. Grain-size analysis was performed by dry sieving at 1 phi $(\Phi)$ intervals with sieves having aperture sizes ranging from 32 to $1 / 32 \mathrm{~mm}(-5 \Phi$ to 5 $\Phi)$. The weight percentages of the sieved fractions were calculated and then plotted as cumulative curves to give the grain-size distribution. Grain-size data were used to define the median diameter $(\mathrm{Md} \Phi)$ and sorting $(\sigma \Phi)$ (Inman, 1952). The proportion of juveniles from -5 $\Phi$ to $0 \Phi$ was defined by hand picking, and from $0 \Phi$ to $1 \Phi$ using the binocular microscope and image analysis techniques (e.g., Image J software). This method allowed the different components of each particle-size class to be identified (Supplementary Material 1).

Whole rock pumice analyses were performed for major elements in four selected samples representative of the SMP (Table 2). Analyses were done by XRF at the Instituto de Geología of Universidad Nacional Autónoma de México (UNAM), following standard sample preparation and analytical techniques (Bernal and Lozano-Santacruz, 2005). Samples were pulverized to a size of $74 \mu \mathrm{m}$ by using a ceramic alumina container and a shatter box. Results are shown in Table 2. The aim of these analyses was to provide a complete description of SMP characteristics and to compare samples, rather than for a petrogenetic study.

Two samples of organic matter bearing paleosols (Outcrop 1; Figs. 2 and $3 b, c$, and Table 3) were sent to the Beta Analytic Inc. Laboratory of Miami (USA) for radiocarbon dating using the AMS technique (Accelerator Mass Spectrometry- http://www.radiocarbon.com/ accelerator-mass-spectrometry.htm). Samples were collected from two superimposed paleosols just beneath the SMP at the type locality (Temas-1; Fig. 2).

Zircon samples were separated and dated in the Laboratorio de Estudios Isotópicos (LEI), with the Thermo ICAP Qc laser ablation inductively coupled plasma mass spectrometry (LA-ICP-MS). For analysis, we used hand samples from the SMP (Table 3)-removing lithics and altered surfaces-and crushed them. Pumices were crushed, sieved, and panned to obtain a heavy mineral concentrate. This was magnetically separated with a Franz Magnetic Separator and the zircons were handpicked under a binocular microscope. About 50 zircon grains per sample were embedded in a $2.5 \mathrm{~cm}$ diameter epoxy mount. The mount was then polished, scanned under a binocular microscope and with an ELM-3R luminoscope by cathodoluminescence (CL), to obtain images of the interior zircon structure (Marshall and Mariano, 1988).

$\mathrm{U} / \mathrm{Pb}$ analyses were carried out following the methods in Solari et al. (2010), employing a laser beam spot diameter of $23 \mu \mathrm{m}$ using the Plešovice standard zircon (Sláma et al., 2008), as reference material to bracket unknown zircons and allow isotopic ratio calculations. The $\mathrm{U} / \mathrm{Th}$ analyses were carried out using a laser beam of $44 \mu \mathrm{m}$ spot di- 

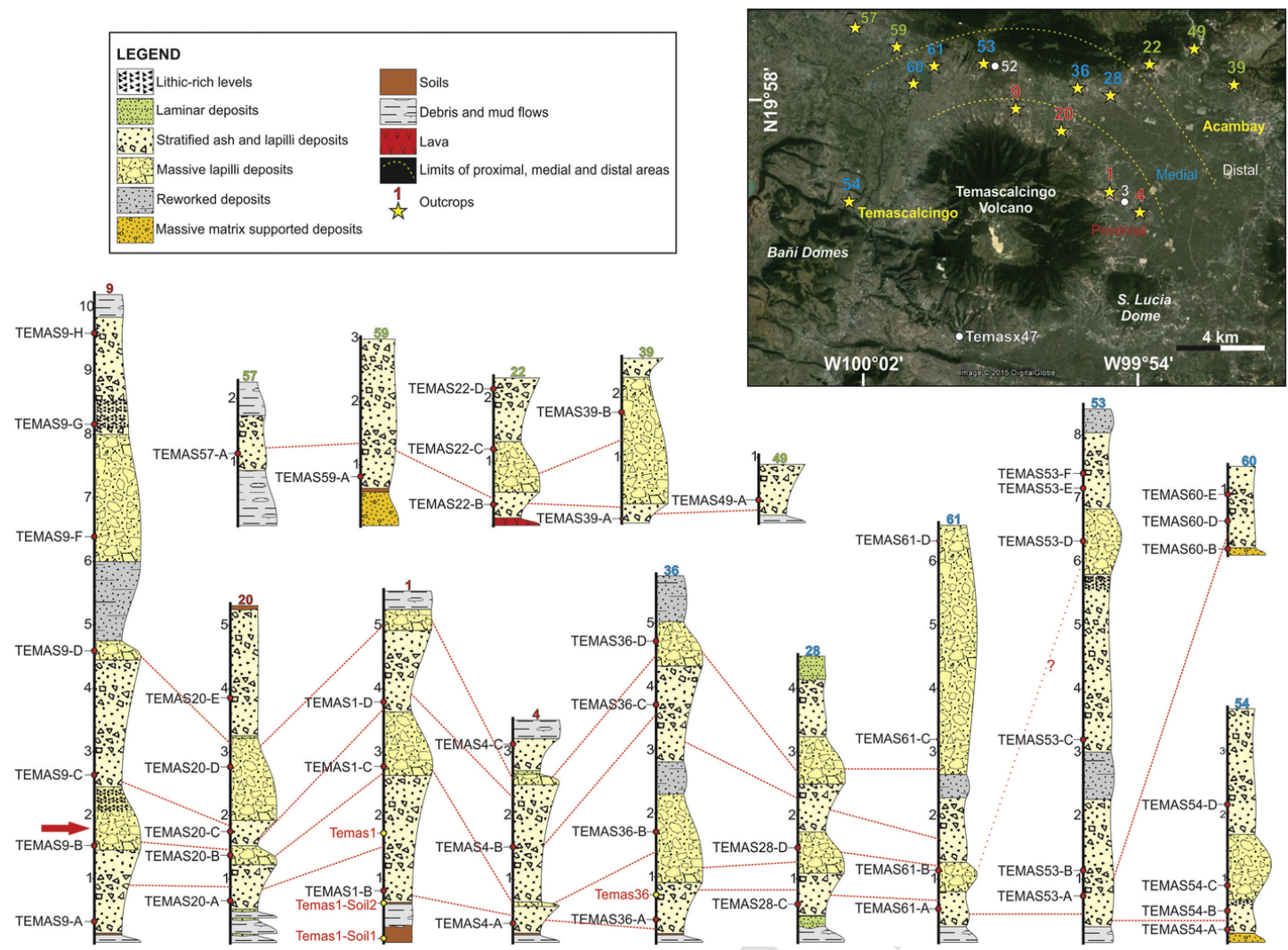

Fig. 2. Representative stratigraphic logs of the SMP (San Mateo Pumice) unit. Inset map shows the location of outcrops and sampling points. See text for further details.

Table 2

Whole-rock chemistry.

\begin{tabular}{|c|c|c|c|c|c|c|c|}
\hline Unit & SMP & SMP & SMP & DADE & DADE & Flank & Flank \\
\hline Sample & TEMAS1 & TEMAS11 & TEMAS36 & $\mathrm{T} 2-8$ & T2-09 & T06-26 & $\mathrm{T} 11-08$ \\
\hline Latitude UTM zone 14 Q & $2,203,301 \mathrm{~m} \mathrm{~N}$ & $2,207,367 \mathrm{mN}$ & $2,208,490 \mathrm{~m} \mathrm{~N}$ & + & + & + & + \\
\hline Longitude UTM zone 14 Q & $404,520 \mathrm{~m} \mathrm{E}$ & $400,551 \mathrm{~m} \mathrm{E}$ & $403,178 \mathrm{~m} \mathrm{E}$ & + & + & + & + \\
\hline $\mathrm{SiO}_{2}$ & 64.7 & 64.3 & 64.6 & 65.6 & 67.2 & 64.2 & 64.9 \\
\hline $\mathrm{TiO}_{2}$ & 0.37 & 0.39 & 0.40 & 0.64 & 0.55 & 0.69 & 0.64 \\
\hline $\mathrm{Al}_{2} \mathrm{O}_{3}$ & 16.5 & 16.5 & 17.7 & 16.0 & 16.9 & 16.4 & 16.4 \\
\hline $\mathrm{FeO}^{*}$ & 3.21 & 3.31 & 3.54 & 3.99 & 3.66 & 4.29 & 4.16 \\
\hline $\mathrm{MnO}$ & 0.05 & 0.05 & 0.05 & 0.05 & 0.03 & 0.06 & 0.06 \\
\hline $\mathrm{MgO}$ & 0.59 & 0.56 & 0.53 & 1.33 & 0.40 & 2.22 & 1.57 \\
\hline $\mathrm{CaO}$ & 1.90 & 2.00 & 1.84 & 3.76 & 3.50 & 4.48 & 4.37 \\
\hline $\mathrm{Na}_{2} \mathrm{O}$ & 2.70 & 2.71 & 2.38 & 3.91 & 4.24 & 3.82 & 4.26 \\
\hline $\mathrm{K}_{2} \mathrm{O}$ & 3.55 & 3.37 & 3.22 & 2.26 & 2.24 & 2.63 & 1.97 \\
\hline $\mathrm{P}_{2} \mathrm{O}_{5}$ & 0.10 & 0.10 & 0.10 & 0.16 & 0.06 & 0.17 & 0.15 \\
\hline LOI & 6.43 & 6.79 & 5.68 & 1.65 & 0.67 & 0.57 & 0.49 \\
\hline SUM & 100.1 & 100.1 & 100.1 & 99.4 & 99.4 & 99.4 & 98.9 \\
\hline
\end{tabular}

SMP: San Mateo Pumice.

DADE: Debris avalanche deposit.

Flank: flank lava flow.

FeO*-total iron; LOI: Lost of ignition.

X-Ray Fluorescence Analyses of preformed in UNAM's Institute of Geology by Rufino Lozano Santacruz and Patricia Girón García.

+ Data from Roldán-Quintana et al. (2011).

ameter, following the methods of Bernal et al. (2014). This technique is more appropriate to zircon date eruptions younger than $350 \mathrm{ka}$, instead of $\mathrm{U} / \mathrm{Pb}$, because they are not in secular equilibrium.

Other samples were sent, irradiated and analysed at the OSU Argon Geochronology Lab, Oregon State University (OSU), using a continuous Ar laserprobe combined with a multi-collector ARGUS-
VI mass spectrometer, following methods described by Koppers et al. (2011) and Balbas (2016). ${ }^{40} \mathrm{Ar} /{ }^{39} \mathrm{Ar}$ age was obtained by laser step-heating techniques. Similar to zircons, we separated the clean pumice and crushed them to obtain mineral concentrations. We sieved the crushed samples and the $180-500 \mu \mathrm{m}$ fraction was washed in deionized water and in an ultrasonic bath to remove dust. Feldspars were 

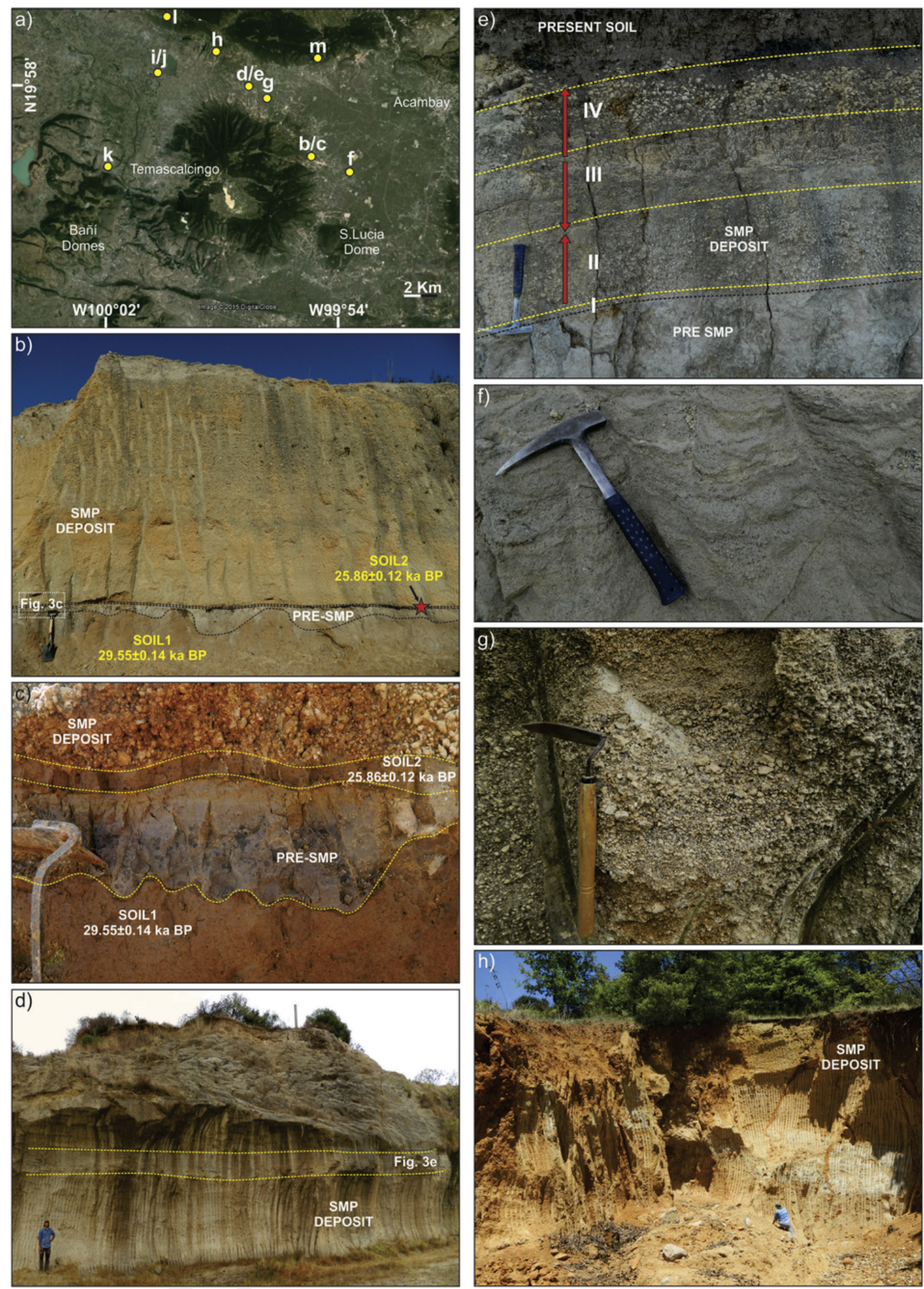

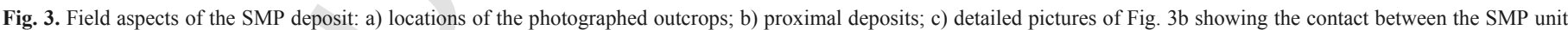

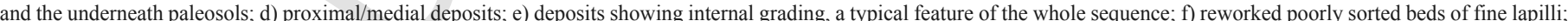

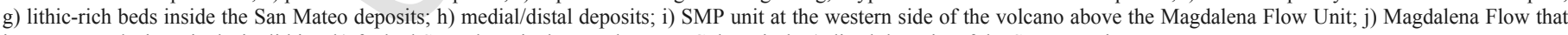
incorporates decimetric dacite lithics; k) faulted SMP deposit above a dense PDC deposit; l-m) distal deposits of the SMP eruption. 

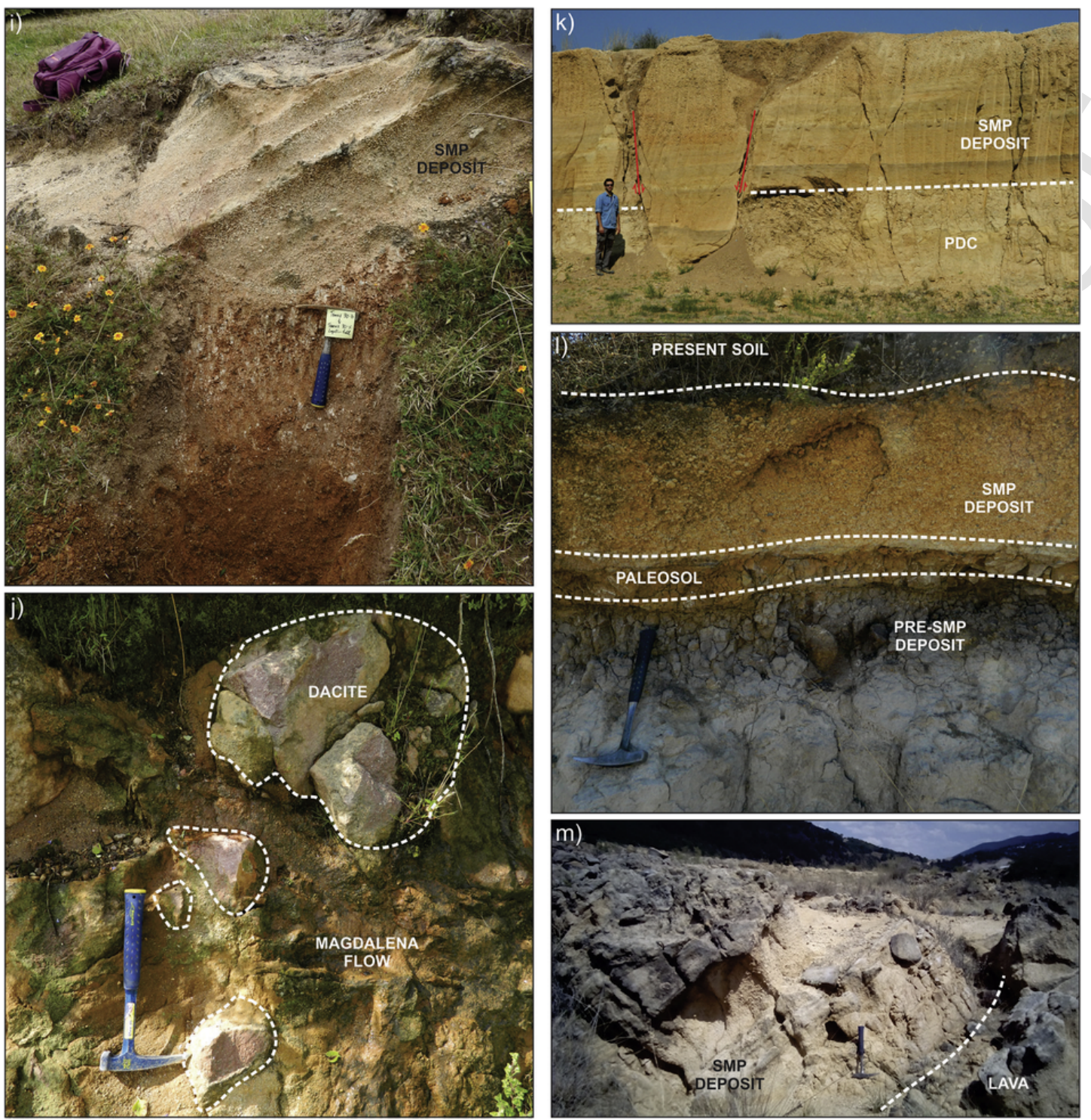

Fig. 3. (Continued)

magnetically separated from amphiboles and quartz and all phases were acid-leached following the methods of Koppers et al. (2011). Inclusion-free plagioclase, was then handpicked under a binocular microscope. We irradiated prepared samples loaded into $\mathrm{Cu}$ planchettes in an ultra high vacuum sample chamber along with a Fish Canyon Tuff Sanidines (28.201 $\pm 0.046 \mathrm{Ma}, 2 \sigma$; Kuiper et al., 2008) flux monitor for $6 \mathrm{~h}$ in the TRIGA CLICIT nuclear reactor, using methods previously described by Koppers et al. (2011).

\section{Stratigraphy and characteristics of the SMP Unit}

The SMP unit corresponds to a succession of pyroclastic deposits with a maximum thickness of $10 \mathrm{~m}$, (Stratigraphic $\log 9$-Fig. 2). These deposits usually overlie older lava flows and mud flows. Sometimes SMP deposits are found directly above previous pyroclastic TV units (Stratigraphic logs 54 and 60-Fig. 2). The SMP deposits are discontinuously covered and eroded by younger reworked deposits of TV (Figs. 2 and 3).
The pyroclastic succession of the SMP unit consists of pumice deposits mainly exposed on the northern and northeast flank of TV and on the scarp of the Acambay-Tixmadeje E-W trending fault (Figs. 1 and 2), covering an area of at least $100 \mathrm{~km}^{2}$. Due to the uniformity of the whole deposit, individual layers are difficult to correlate and tend to merge in distal areas. That is why no subunits were characterised. 15 representative outcrops (Fig. 2) were selected for stratigraphic, grain size and componentry studies, being the most representative of the eruptive sequence.

In general, SMP deposits show normal and inverse size grading, lack of internal bedding features, mantle bedding and ballistic clasts.

At proximal locations (Stratigraphic $\operatorname{logs} 1,4,9,20$ - Fig. 2) deposits consist of a rhythmic alternation of well-sorted thick $(30-100 \mathrm{~cm})$ to very thick $(>100 \mathrm{~cm})$ beds of coarse and fine pumice lapilli with bombs and exposed thicknesses up to $8-10 \mathrm{~m}$ (Fig. 3d, e). Some reworked, poorly-sorted (Fig. 3f), thick $(30-100 \mathrm{~cm}$ ) beds of fine pumice lapilli are observed at some of the outcrops in the succession (Stratigraphic log 9-Fig. 2), as well as lava lithic-rich beds (Fig. $3 \mathrm{~g}$ ) in a finer matrix. Grain size distribution of the proximal de- 
Table 3

Conventional ages of SMP eruption samples.

\begin{tabular}{|c|c|c|c|c|}
\hline Sample & $\begin{array}{l}\text { Latitude } \\
\text { UTM } \\
\text { zone } 14 \\
\text { Q }\end{array}$ & $\begin{array}{l}\text { Longitude } \\
\text { UTM } \\
\text { zone } 14 \text { Q }\end{array}$ & Methods & Age \\
\hline TEMAS-1 & 404,520 & $2,203,301$ & $\begin{array}{l}\text { Zircon (U/ } \\
\text { Th) }\end{array}$ & $>356 \pm 52 \mathrm{ka}$ \\
\hline TEMAS-36 & 403,178 & $2,208,490$ & $\begin{array}{l}\text { Zircon (U/ } \\
\text { Th })^{\mathrm{a}}\end{array}$ & $>397 \pm 76 \mathrm{ka}$ \\
\hline TEMAS-52 & 398,768 & $2,209,410$ & $\begin{array}{l}\text { Zircon (U/ } \\
\text { Th })^{\mathrm{a}}\end{array}$ & $>371 \pm 61 \mathrm{ka}$ \\
\hline TEMAS-36 & 403,178 & $2,208,490$ & $\begin{array}{l}\text { Zircon }(\mathrm{U} / \\
\mathrm{Pb})\end{array}$ & $1.862 \pm 0.047 \mathrm{Ma}$ \\
\hline TEMAS-3 & 406,232 & $2,202,292$ & $\begin{array}{l}\text { Plagioclase } \\
\text { (Ar/Ar) }\end{array}$ & $2.13 \pm 0.12 \mathrm{Ma}$ \\
\hline TEMAS-1Soil1 & 404,520 & $2,203,301$ & $\begin{array}{l}\text { AMS } \\
\text { technique }\end{array}$ & $\begin{array}{l}29.660 \pm 0,140 \mathrm{ka} \\
\text { BP }\end{array}$ \\
\hline TEMAS-1Soil2 & 404,520 & $2,203,301$ & $\begin{array}{l}\text { AMS } \\
\text { technique }\end{array}$ & $\begin{array}{l}25.860 \pm 0,120 \mathrm{ka} \\
\mathrm{BP}\end{array}$ \\
\hline Temax 47a & 397,427 & $2,196,369$ & $\begin{array}{l}\text { AMS } \\
\text { technique }\end{array}$ & $\begin{array}{l}37.490 \pm 0,330 \mathrm{ka} \\
\mathrm{BP}\end{array}$ \\
\hline
\end{tabular}

${ }^{a}$ Results from these analyses are only reported here for comparison and were excluded from further considerations because the SMP eruption age is outside of the superior method limit. See text for more details.

posits is characterised by $\mathrm{Md}(\Phi)$ and sorting varying between -2.83 and $-1.31 \Phi$ and 1.42 and 2.22, respectively (Fig. 4).

At medial locations (Stratigraphic logs 28, 36, 53, 54, 60 and 61-Fig. 2) the SMP unit reaches thicknesses up to 6-8 m (Fig. 3h) and displays internal stratification, with well to poorly sorted, medium-thick $(10-30 \mathrm{~cm})$ beds to thick $(30-100 \mathrm{~cm})$ beds of pumice lapilli with gradational coarse-fine-coarse graded bedding. Grain size distribution is characterised by $\mathrm{Md}(\Phi)$ and sorting varies between -3 and $0.9 \Phi$ and 1.2 and 2.4, respectively (Fig. 4).

At Outcrop 60 (Fig. 2), there is a lithic-rich deposit with a notable inverse grading. (Fig. 3i) above a homogeneous massive deposit (Fig. 3j), previously interpreted as the Magdalena Flow Unit by Roldán-Quintana et al. (2011). The non-welded Magdalena deposit shows a yellow to grey ash matrix with fine pumice lapilli, and contains $<1 \%$ of small clasts $(<2 \mathrm{~cm})$ of white pumice lapilli with phenocrysts of plagioclase and hornblende and $\sim 20-30 \%$ of dacitic lava lithics. No evidence of paleosols or sedimentary deposits was observed between the deposits. The total thickness of the Magdalena Flow deposit is unknown since it has not been fully observed, either because it is partially covered by alluvium and recent lacustrine deposits of the Solis valley or due to the lack of natural or artificial outcrop that exposes it completely. At the same outcrop, the Magdalena Flow Unit overlies the DAE Unit (Fig. 3j), which is an avalanche deposits, characterised by a grey porphyritic dacite as the only component. The larger clasts generally show jigsaw fractures. This unit, previously described by Roldán-Quintana et al. (2011), is found in the area from the TV amphitheatre (Fig. 2c) and is distributed to the west at a distance of up to $6 \mathrm{~km}$. The contact between the DAE Unit and the Magdalena Unit, which has a distribution very similar to that of the avalanche deposit, is continuous, without evidence of paleosols or sedimentary deposits (Roldán-Quintana et al., 2011).

To the east (Stratigraphic log 54-Fig. 2), the SMP deposit occurs above a massive, homogeneous yellow brown deposit (Fig. 3k), with similar characteristics to that observed at Outcrop 60 (Fig. 3i). The whole sequence is affected by normal faults with similar orientations as the main faults of the Acambay graben (ESE-WNW; Fig. 3k).

In distal areas (Stratigraphic logs 22, 39, 49, 57 and 59-Fig. 2) deposits show a well-sorted, medium-thick $(10-30 \mathrm{~cm})$, non-welded, massive bed of pumice lapilli (Fig. 31,m). At Outcrop 59 (Fig. 2), a massive deposit similar to those of outcrops 60 and 54 (Fig. 2) can be observed, and a small, poorly-developed paleosol is present between this unit and the SMP.

The grain size distribution of these samples is characterised by $\mathrm{Md}$ $(\Phi)$ and sorting varying between -2 and $-0.26 \Phi$ and 1.26 and 2.1 , respectively (Fig. 4).

Lithic clasts predominantly consist of dacitic lava fragments of TV and juvenile clasts consisting of poorly vesiculated, crystal-poor, angular-to-subangular, yellow-to-grey pumice lapilli (Fig. 2). Lithics content is mostly constant in all deposits with values around $5-7 \%$ wt. (Supplementary Material 1) increasing only in some levels reaching around $15-17 \%$ (e.g., samples Temas-1E, Temas4-A, Temas4-C, Temas22-D, Temas36-B, Temas54-B, and Temas61-B- Supplementary Material 1).

\section{Isopach and Isopleth maps}

An isopach map (Fig. 5a) of the SMP unit was reconstructed from field measurement using 35 stratigraphic logs (Table 1). These outcrops represent the most complete sequence of the SMP eruption. Preliminary isopleth maps (juvenile pumices (Fig. 5b), and dacitic lava lithics (Fig. 5c) and Table 1) were also reconstructed for the first climactic phase of the eruption as indicated by a red arrow in Fig. 2. We were able to reconstruct isopach and isopleth maps only on the northern and north-eastern side of the TV because of the difficulty of correlating different stratigraphic levels of the SMP and due to the lack of deposits in the other areas; most of the outcrops show eroded tops as well. This is why only a relatively small number of measurement sites was reported (Table 1). The most distal exposure of the SMP unit (Fig. 5) is found about $10 \mathrm{~km}$ from the thickest deposit outcrop (Outcrop 49; Fig. 2). The isopleth maps are based on measurements of the five largest juvenile pumice and lithic clasts from each of 35 locations (Fig. 5b and $\mathrm{c}$ and Table 1). The largest pumice and lithics clasts, respectively $\sim 4$ and $\sim 2 \mathrm{~cm}$ in diameter were found in the northern part of TV (Fig. 5b,c). All three maps show a NE dispersion trend, thus suggesting a source to the west of TV (Fig. 5).

\section{Geochemistry and petrography}

The SMP juvenile fragments are dacite (Fig. 6a and Table 2), similar to other deposits of TV (Aguirre-Díaz et al., 2015) as shown in Table 2. There is little variation in alkalies and silica contents for the SMP unit (Table 2 and Fig. 6a), and they have medium to high $\mathrm{K}_{2} \mathrm{O}$ contents (Fig. 6b). Compositional ranges in $\mathrm{wt} \%$ are $\mathrm{SiO}_{2}=64.3-64.7$, $\mathrm{Al}_{2} \mathrm{O}_{3}=16.5-17.7, \quad$ Total $\mathrm{FeO}=3.21-3.54, \quad \mathrm{MgO}=0.53-0.59$, $\mathrm{CaO}=1.84-2.0, \mathrm{NaO}_{2}=2.38-2.70, \mathrm{~K}_{2} \mathrm{O}=3.22-3.55$ (Table 2).

Pumice fragments are microporphyritic, with scattered phenocrysts $(<10 \%$ in volume) surrounded by a glassy matrix with fluidal texture (Fig. 7a). The mineral assemblage consists of subhedral to anhedral quartz (Fig. 7b), plagioclase (Fig. 7c), and amphiboles (Fig. 7d). The same phases were also found in the groundmass, along with Fe-Ti oxides and glass. The maximum size of the phenocrysts is $0.5 \mathrm{~mm}$ for quartz and $1 \mathrm{~mm}$ for amphibole and plagioclase.

\section{Geochronology}

Two samples were collected from two superimposed paleosols just beneath the SMP deposits at the type locality (Temas-1; Fig. 2). The lower soil, dark brown clay (Temas1-Soil1 Stratigraphic log 1-Fig. 2 and Fig. 3b,c) has a ${ }^{13} \mathrm{C} /{ }^{12} \mathrm{C}$ ratio of $-18.0 \%$, corresponding to a conventional age of $29.660 \pm 0.140$ ka years $\mathrm{BP}$ and a calibrated radiocarbon age of $29.550 \pm 0.140$ kayears BP (Table 3 ). The upper paleosol is a dark grey clay (Temas1-Soil2-Stratigraphic log 1-Fig. 2 


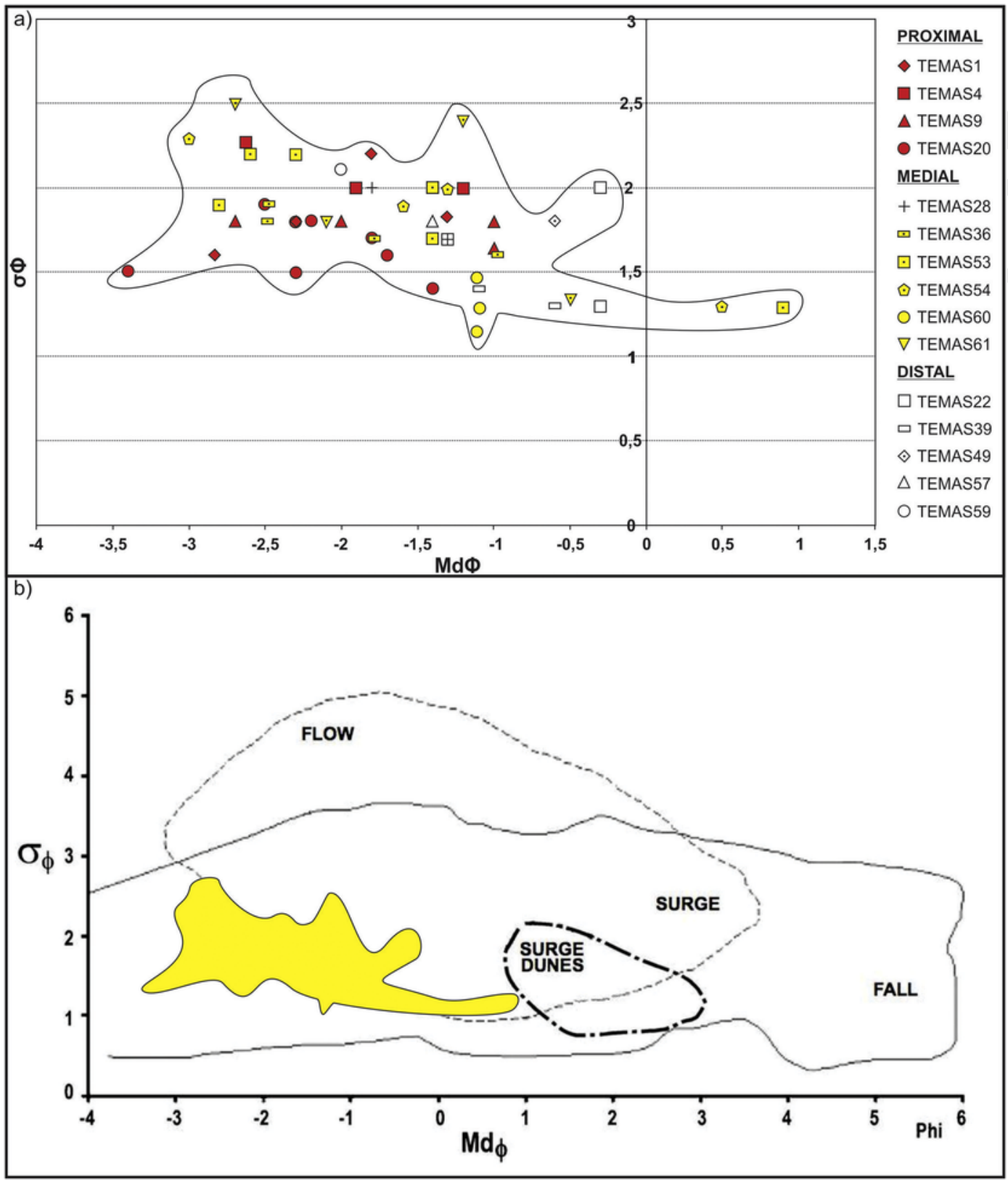

Fig. 4. a) Sorting $(\sigma \phi)$ versus median diameter (Mdф) plot of grain-size data from the SMP unit; b) grain-size data from the SMP, plotted in the Walker diagram (Walker, 1971).

and Fig. $3 \mathrm{~b}, \mathrm{c})$ with a ${ }^{13} \mathrm{C} /{ }^{12} \mathrm{C}$ ratio of $-18.4 \%$, corresponding to a conventional age of $25.860 \pm 0.120$ ka years BP and to a calibrated radiocarbon age of $25.750 \pm 0.120$ ka years BP (Table 3). The specimen age (i.e., laboratory number Beta-408957) was determined after the IntCal13 calibration curve (Reimer et al., 2013).

For age comparison, we report here another dated sample with the ${ }^{14} \mathrm{C}$ technique from a different pumice eruption of TV. It is a black paleosol (Temax47a; location shown in Fig. 2), which is beneath a $2 \mathrm{~m}$ thick pumice fall deposit. Results from the Beta Analytics Laboratory indicate a conventional radiocarbon age of $37.490 \pm 0.330$ ka years $\mathrm{BP}$, and a calibrated age of $40.450-39.461 \mathrm{kacalBC}(42.399 \mathrm{ka}-$ 41.410 ka cal BP) (Table 3).

Three samples from SMP pyroclastic deposits were collected for radiogenic U/Th zircon analyses: Temas-1, Temas-36, and Temas-52
(Fig. 2) that gave respectively ages of $356 \pm 52 \mathrm{ka}, 397 \pm 76 \mathrm{ka}$ and $371 \pm 61 \mathrm{ka}$ (Table 2). U/Th ages indicate secular equilibrium (Bernal et al., 2014) and that is why results from these analyses were excluded from further considerations because the SMP eruption age is outside of the superior method limit. One sample (Temas-36; Fig. 2) was prepared for radiogenic $\mathrm{U} / \mathrm{Pb}$ zircon analyses. The ages were calculated with the intersection of the Concordia curve and the normal isochron using the Isoplot software (v. 3.7), and following the methods of Ludwig (2008). To obtain the best possible results, the data of the most discordant zircons (major ellipsoids) were discarded. This results in an age of $1.862 \pm 0.047 \mathrm{Ma}$ (Table 3).

A plagioclase concentrate from sample Temas-3 (Fig. 2) was ${ }^{40} \mathrm{Ar} /{ }^{39} \mathrm{Ar}$ dated using a large number of heating steps in order to achieve the highest possible precision (Koppers et al., 2011). Age 

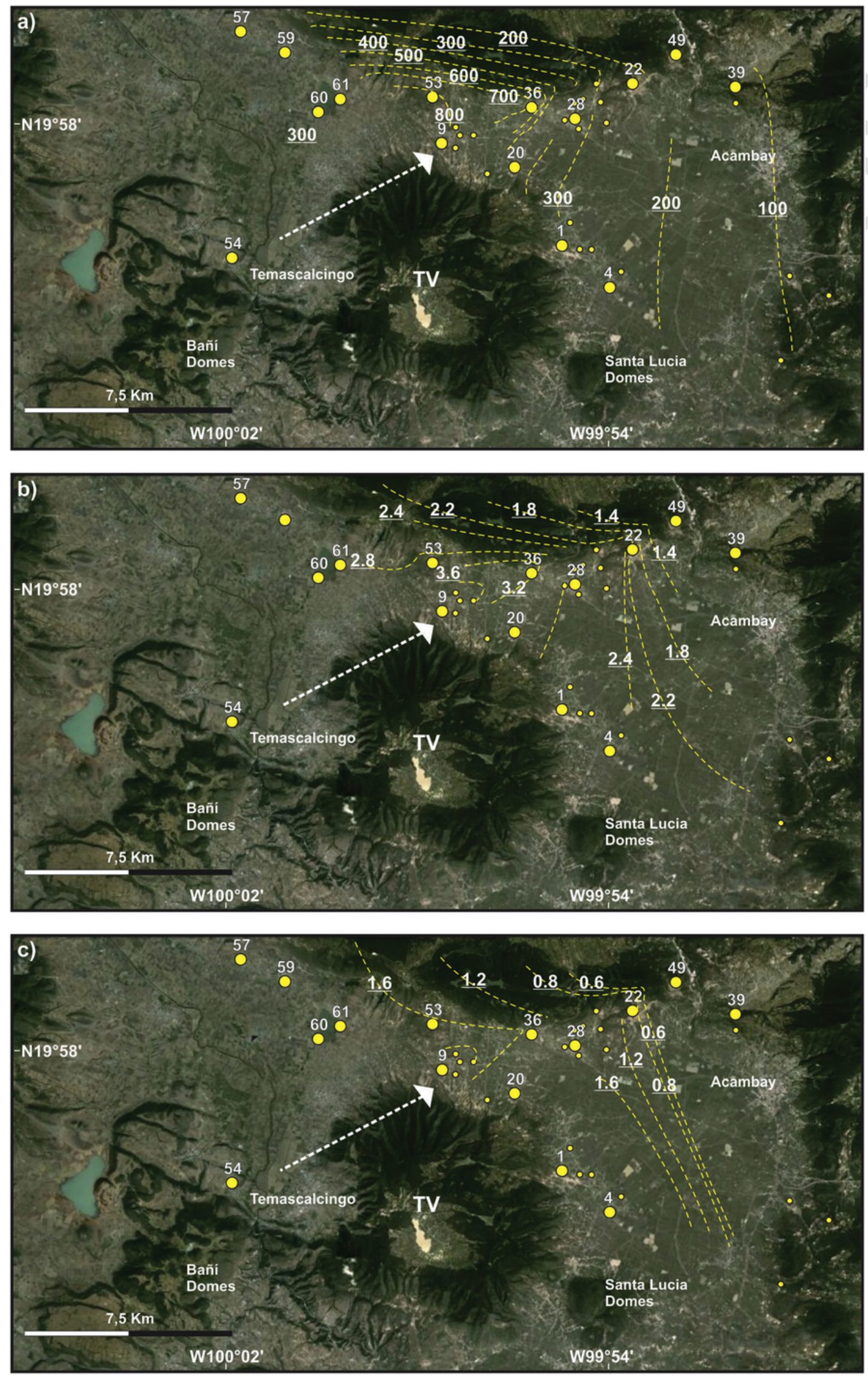
plateaus included as many contiguous and concordant step ages as possible. Before analysing a sample, and after every three heating steps, system blanks were measured. In this way, after the first 7 to 14 low temperature steps, an adequate amount of discordant gasses were released from alterations remaining and atmospheric contamination. This yielded an age of $2.13 \pm 0.12 \mathrm{Ma}$. To get the appropriate eruption timing it was necessary to recalculate the ages using the Kuiper et al. (2008) age for the Fish Canyon Tuff as a flux monitor, reducing the data with the ArArCALC v2.5.1 software from Koppers (2002). ${ }^{40} \mathrm{Ar} /{ }^{39} \mathrm{Ar}$ age errors reported here are $2 \sigma$. More details of the techniques employed in the dating process are provided in Koppers et al. (2011) and Balbas (2016).

\section{Eruptive parameters of the SMP Unit}

\subsection{Volume}

Volume of the eruption was calculated by applying the methods of exponential, power-law and Weibull integrations (Pyle, 1989; Bonadonna and Houghton, 2005; Bonadonna and Costa, 2012; Table $3)$. The calculated volumes are $0.20 \mathrm{~km}^{3}$ from the exponential integrations, $0.27 \mathrm{~km}^{3}$ for the power-law integrations (different volumes were calculated based on variable distal limits of integrations-from 0.27 to $1.96 \mathrm{~km}^{3}$ ), and $0.27 \mathrm{~km}^{3}$ for the Weibull integration (Table 4). The erupted mass, based on the volume obtained from the Weibull integration, was, respectively, $1.44 \times 10^{11} \mathrm{~kg}$ based on a deposit density of $534 \mathrm{~kg} / \mathrm{m}^{3}$ (Table 4). The associated DRE volume, based on a deposit density of $534 \mathrm{~kg} / \mathrm{m}^{3}$ and a magma density of $2500 \mathrm{~kg} / \mathrm{m}^{3}$ was estimated at $0.05 \mathrm{~km}^{3}$.

\subsection{Plume height, wind speed, mass eruption rate, and eruption duration}

Plume height and wind velocity at the time of the eruption were derived by applying the method of Carey and Sparks (1986) to the isopleth map, considering the vent to be the present amphitheatre of the volcano on the western side. Thus, it is possible to estimate a maximum plume height of about $12 \mathrm{~km}$ above the vent (i.e., about $14 \mathrm{~km}$ above sea level) and wind velocities of up to $30 \mathrm{~m} / \mathrm{s}$. The SMP deposit was mainly dispersed north-eastward (Fig. 5).

The peak mass eruption rate (MER) was calculated by applying the method of Wilson and Walker (1987) and Mastin et al. (2009) (Table $4)$, resulting in a MER of $6.7 \times 10^{6} \mathrm{~kg} / \mathrm{s}$ and $4.2 \times 10^{6} \mathrm{~kg} / \mathrm{s}$, respectively. The eruption duration was estimated between 6 and $9.3 \mathrm{~h}$ based on the ratio between erupted mass and the two MER values described above (Table 4).

\subsection{Classification}

Based on the volume described previously and on the observed field characteristics, the SMP eruption is classified as having a Volcanic Explosivity Index (VEI) of 4 (Newhall and Self, 1982). Using the scales of Pyle (2000), the associated magnitude is 4.2, and the intensity is between 9.6 and 9.8 (Table 4). According to the semi-log plot of thickness versus the square root of the deposits' area (Fig. 8a), the SMP eruption can be classified as a subplinian to plinian eruption, whilst on the diagram of Bonadonna and Costa (2013; MER vs.
Plume Height) it results from a transition between a moderate to subplinian eruption (Fig. 8b).

\section{Fallout scenario simulations}

Fallout scenarios were obtained using the VORIS 2.0.1 tool, an advection diffusion model that assumes that particles transport in a Plinian eruption is controlled by the wind advective effect, the atmospheric turbulence diffusion and the particles settling velocity (Felpeto et al., 2007). Input data on the eruptive column and ash particle size were inferred from the field deposit. We simulated one scenario (Fig. 9a) with eruptive parameters gathered from the deposit assuming a subplinian eruption to indicate how ashfall could be dispersed in a similar future eruption. For this scenario we considered a maximum column height of $12 \mathrm{~km}$ from a vent $2000 \mathrm{~m}$ high (X: 397565; Y: $2200959)$, with a total emitted volume of $0.27 \mathrm{~km}^{3}$ obtained with the Weibull integration (Table 4), and grain-particle size ranging from -5 $\Phi$ to $5 \Phi$. A particle density of $2500 \mathrm{~kg} / \mathrm{m}^{3}$ was given for the dacitic material. For the atmospheric and wind data we considered $1500 \mathrm{~m}$ for horizontal diffusion and $12,000 \mathrm{~m}$ for the tropopause height. Wind direction and intensity were chosen at different vertical heights $(2000$, $4000,6000,10,000$, and 12,000 m; see Fig. 9a for more details). This first scenario simulation did not fit the real isopach pattern of SMP eruption. Therefore, trying to reproduce the best SMP fit, we simulated a second scenario (Fig. 9b) using a volume of $0.9 \mathrm{~km}^{3}$ inferred from the isopach map, and the same column height, particle size, density and atmospheric data used in the first case. We refined the wind direction data and intensity information at the different vertical heights in order to get the most similar simulation to the reality (Fig. 9b).

\section{Discussion}

\subsection{Physical volcanology of the SMP Unit}

The stratigraphy, lithology and depositional features of the SMP deposits allowed for the reconstruction of its eruptive dynamics and main physical parameters. The products of this eruption cover at least $100 \mathrm{~km}^{2}$; however, its original extent is inferred to have been larger (Fig. 9). SMP deposits were mainly found on the northern area of the Acambay graben, to the north of TV, although some scattered outcrops are also located in the western part of TV (Fig. 5).

The SMP eruption was characterised by a single magmatic event: lithic fragments, the absence of particle aggregates, such as accretionary and armoured lapilli, well-vesiculated juvenile products and a low proportion of fine particles, are unambiguous evidence of magmatic activity. The eruption was continuous, due to the lack of paleosols or erosional surfaces within the deposit, and there being no associated lava flow. The lithological and depositional characteristics of the SMP deposits observed in the field, such as normal and inverse size grading, lack of internal bedding features, mantle bedding and ballistic clasts (Fig. 3), indicate fallout deposits with few dilute PDC currents (Fig. 2).

The stratigraphy of the SMP eruption suggests an initial phase with many short-lived pulses, as seen in Stratigraphic log 60 (Fig. 3i), with differing grain sizes (Houghton and Carey, 2015). Another possible cause of grain size oscillations, especially in plinian deposits,

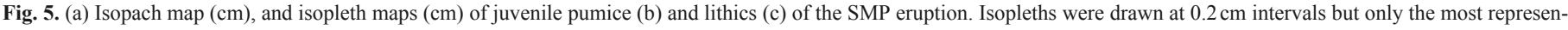

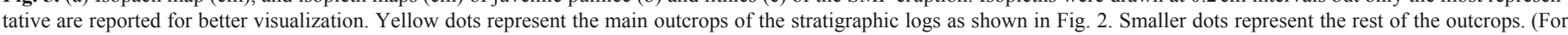
interpretation of the references to colour in this figure legend, the reader is referred to the web version of this article.) 

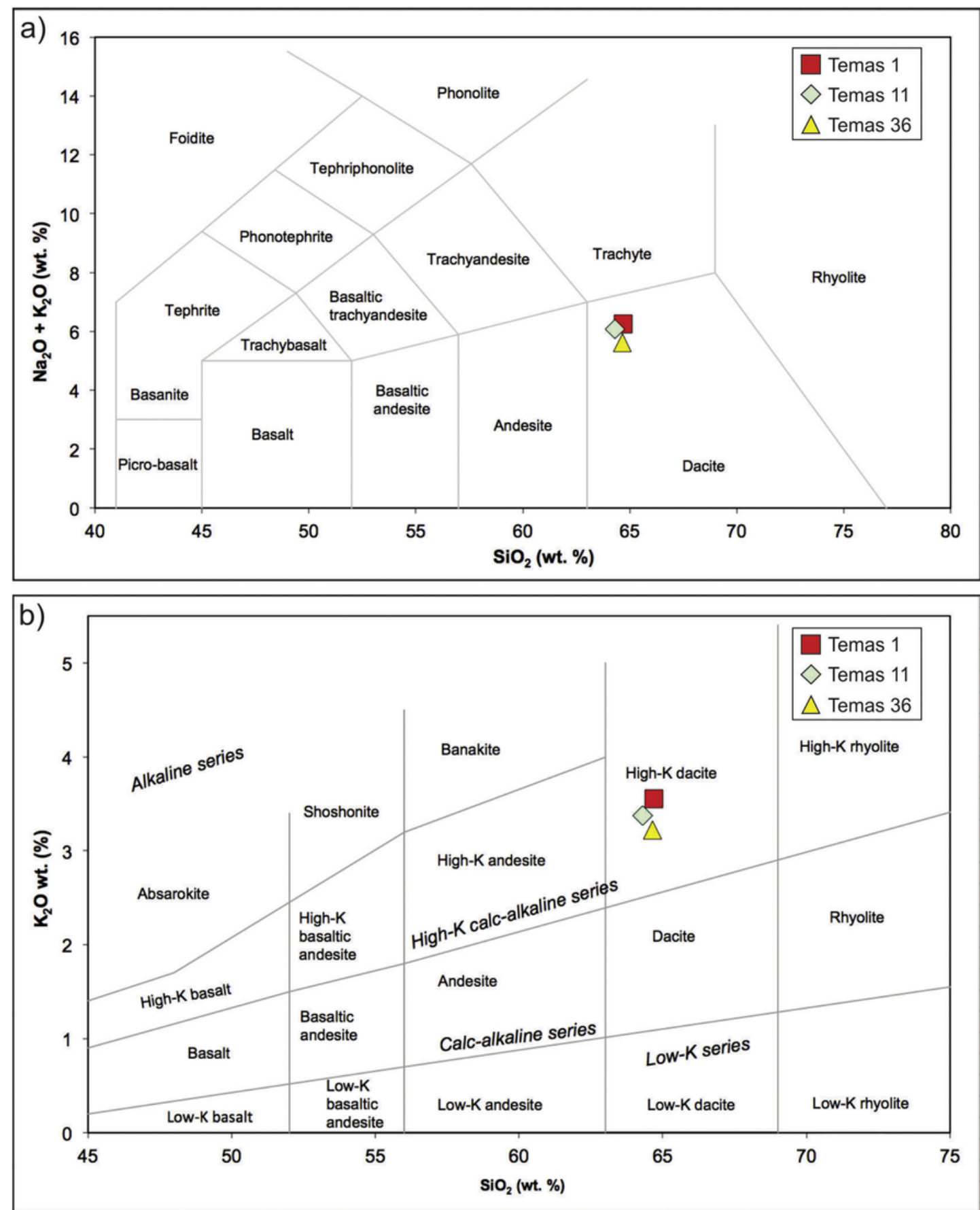

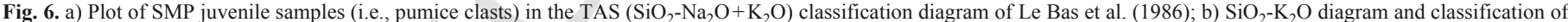
Peccerillo and Taylor (1976). Other units of TV are also reported for comparison.

might be related to the occurrence of partial column collapses (Houghton and Carey, 2015), but no PDC collapse-related deposits were found in the area. The eruption continued to form deposits with coarser and finer normal and inverse grained intervals, without discrete bedding planes. Size grading can be interpreted as a main climactic phase with steady pulses (Fig. 3b, d, h) that produce massive, uniform deposits, with small fluctuations in eruptive intensity, as shown in the deposits located in the northern part of the Acambay area (Fig. 2).
The eruption was characterised by repeated clearing of the conduit, as deduced by the presence of dacitic lava lithic-rich layers. Indeed, the lithic content is nearly constant in most deposits with values $5-7 \mathrm{wt} \%$ (Supplementary Material 1), but at some levels, there is an increase to $15-17 \mathrm{wt} \%$ (e.g., samples Temas-1E, Temas4-A, Temas4-C, Temas22-D, Temas36-B, Temas54-B, and Temas61-BSupplementary Material 1), resulting in increased density of the erupting mixture (Sulpizio et al., 2005). These lithics belong to the volcano substrate as suggested by Roldán-Quintana et al. (2011), who identi- 

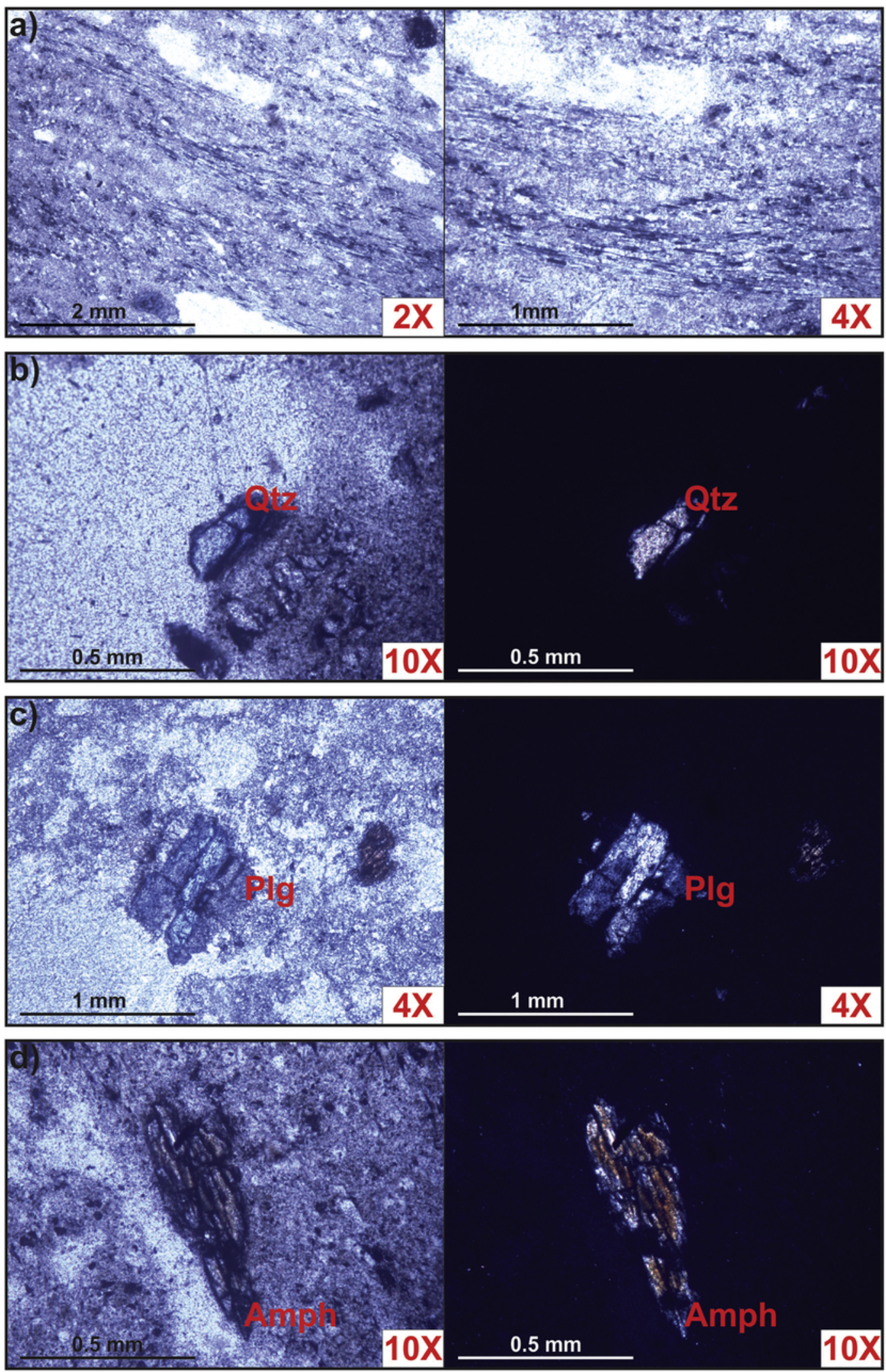

Fig. 7. Petrographic features of the SMP eruption products: parallel nicols a) fluidal texture, parallel and crossed nicols; b) quartz; c) plagioclase; d) amphibole. 
Table 4

Physical parameters of SMP eruption.

\begin{tabular}{lllll}
\hline & $\begin{array}{l}\text { Volume } \\
\left(\mathrm{km}^{3}\right)\end{array}$ & Mass $\left(\times 10^{11} \mathrm{~kg}\right)^{\mathrm{h}}$ & $\begin{array}{l}\text { DRE } \\
\left(\mathrm{km}^{3}\right)^{\mathrm{i}}\end{array}$ & Magnitude $^{\mathrm{g}}$ \\
\hline Exponential $^{\mathrm{a}}$ & 0.2 & 1.1 & 4 \\
Power Law $^{\mathrm{b}}$ & 0.27 & 1.44 & 4.1 \\
& 0.42 & 2.24 & 4.3 \\
& 0.63 & 3.36 & 4.5 \\
Weibull $^{\mathrm{c}}$ & 1.09 & 10.1 & 5 \\
& 1.96 & 10.4 & 5 \\
Plume Height & 0.27 & 1.44 & 4.1 \\
$(\mathrm{~km})^{\mathrm{d}}$ & 12 & Eruption & Intensity \\
$\mathrm{MER}\left(\times 10^{6}\right)$ & 6.7 & duration $(\mathrm{h})^{\mathrm{j}}$ & & \\
$\mathrm{Kg} / \mathrm{s}^{\mathrm{e}}$ & & 6 & & 9.8 \\
$\mathrm{MER}\left(\times 10^{6}\right)$ & 4.2 & 9.3 & & \\
$\mathrm{Kg} / \mathrm{s}^{\mathrm{f}}$ & & & & \\
$\mathrm{VEI}^{\mathrm{k}}$ & 4 & & & \\
\hline
\end{tabular}

a Pyle, 1989.

b Bonadonna and Houghton, 2005.

c Bonadonna and Costa, 2012, 2013.

${ }^{d}$ Carey and Sparks (1986).

e Wilson and Walker (1987).

${ }^{f}$ Mastin et al. (2009).

g Pyle, 2000.

h Based on Weibull integration and on a deposit density of $534 \mathrm{~kg} / \mathrm{m}^{3}$.

i Based on a deposit density of $534 \mathrm{~kg} / \mathrm{m}^{3}$ and a magma density of $2500 \mathrm{~kg} / \mathrm{m}^{3}$.

${ }^{\mathrm{j}}$ Ratio between erupted mass and MER values.

k Newhall and Self, 1982.

fied them in the Magdalena Flow, the predominance of a single type of lithic of porphyritic dacite.

The SMP eruption produced a vigorous plume reaching up to $12 \mathrm{~km}$ above the vent, (14 km above sea level), with a main dispersion axis in a SW-NE direction (Fig. 9). Total bulk volume obtained from field data was $0.27 \mathrm{~km}^{3}$ and the peak mass eruption rate was between $4.2 \times 10^{6} \mathrm{~kg} / \mathrm{s}$ and $6.7 \times 10^{6} \mathrm{~kg} / \mathrm{s}$ (Table 4). The SMP deposits are consistent with a subplinian eruption, comparable to other subplinian to moderate plinian events in terms of deposit dispersal, erupted volume, and thinning trend as shown in Fig. 8. On the scales of Pyle (2000), the associated magnitude is 4.2 and the intensity is 9.8 (Table 4). From the volume determined and the observed field characteristics, SMP is characterised by an explosivity index (VEI) of 4, which is similar to Mt. Pelée (1902), Soufriére (1902), Colima (1913), Rabaul (1937), or Fuego (1974; Newhall and Self, 1982).

\subsection{Numerical simulations}

In order to better constrain the SMP eruption, we performed numerical simulations. Fallout scenario simulations show the deposit distribution of a likely future eruption considering the minimum volume $\left(0.27 \mathrm{~km}^{3}\right)$ calculated from the SMP erupxtion (Fig. 9a), and the fallout distribution that better fits the real remaining deposit in the field (Fig. 9b). The first simulation was done in order to show how a subplinian eruption similar to that of SMP occurred, but considering how current winds could affect the surrounding areas of the volcano. Since this scenario did not fit the real remaining distribution of the SMP deposits, we performed several simulations whilst changing the input parameters - mainly volume and winds - to get the most accurate fallout distribution according to the field deposit. In this sense, we constrained the parameters that more precisely would have represented the real eruption, obtaining a total erupted volume circa
$0.9 \mathrm{~km}^{3}$ and having different wind directions and intensities (Fig. 9b). Volumes obtained were within the range of volumes calculated by the power-law method, from 0.27 to $1.96 \mathrm{~km}^{3}$ (see Section 7 and Table 4). The maximum run out distance of the deposits, obtained with the fallout simulation corresponds to the value of power-law integration with a volume of $0.9 \mathrm{~km}^{3}$ (Table 4), giving a maximum distance of $75 \mathrm{~km}$. This implies a plinian eruption, bigger than previously thought and as observed in the field. However, we have to keep in mind that part of the deposit might have been eroded, meaning that a slight major eruptive volume could have been involved.

\subsection{Composition and ages of the SMP Unit}

The chemical and petrographic characteristics (Figs. 6 and 7) of the SMP Unit indicate compositions and textures similar to many stratovolcanoes of the TMVB, in particular, to the most well-known, such as Pico de Orizaba, Popocatépetl, Nevado de Toluca, and Iztaccihuatl (Robin, 1984; Aguilar and Verma, 1987; Nixon, 1988; Rossotti et al., 2006), but also to the lesser known modest size stratovolcanoes, such as its neighbour, Jocotitlán volcano, La Joya volcano, and many others in this volcanic province (Valdéz-Moreno et al., 1998; Siebe et al., 1992; Wallace and Carmichael, 1994). These characteristics include porphyritic textures with large phenocrysts of plagioclase, hornblende and pyroxenes, and andesitic-to-dacitic whole-rock compositions, -generally with textural evidence of mixing and mingling of magmas.

Concerning the age of the SMP Unit, some discrepancies have been found. On the one hand, paleosols directly underneath the deposit yielded 20 to $25 \mathrm{ka}$ ages (Paleosol 1 and 2-Temas-1; Fig. 2 and Table 3 ). However, the timing could be much younger than previously reported (Aguirre-Díaz, 1996) and as mentioned in more recent works (Aguirre-Díaz et al., 2013).

A third paleosol (Outcrop Temax47a; Fig. 2 and Table 3) found on the southern flank of the volcano yielded and age of about $42 \mathrm{ka}$. This paleosol underlies a $2 \mathrm{~m}$ thick pumice fall from TV, different than that of the SMP eruption. This would confirm the possibility that TV had activity in the Pleistocene.

In any case, radiometric ages obtained with $\mathrm{U}-\mathrm{Pb}$ and $\mathrm{Ar}-\mathrm{Ar}$ techniques are discordant with the previous ones, yielding a crystallization age of $=1.862 \pm 0.047 \mathrm{Ma}$ (Temas 36; Fig. 2 and Table 3 ) with the $\mathrm{U} / \mathrm{Pb}$ method, and an eruption age of $2.13 \pm 0.12 \mathrm{Ma}$ (Temas 3; Fig. 2 and Table 3) with the Ar/Ar technique. Concerning the U/Pb and $\mathrm{Ar} / \mathrm{Ar}$ techniques that both gave an age of approximately $2 \mathrm{Ma}$, the data is consistent with the eroded morphology of the TV (Fig. 2). If we consider the fault escarpment of the San Mateo fault (one of four that cuts the volcano) between 100 and $200 \mathrm{~m}$ (Sunyé-Puchol et al., 2015), the displacement rate would be about 0.05 to $0.1 \mathrm{~mm} /$ year, which is the same for the fault system in the Acambay Graben (Suter et al., 2001). The same displacement rate was calculated in the trenches for paleoseismological purposes (Fig.1c) close to TV (Ortuño et al., 2015; Lacan et al., 2017) giving values from 0.05 to $0.1 \mathrm{~mm} /$ y. This would correspond to an age of about $2 \mathrm{Ma}$, which might coincide with the $\mathrm{Ar} / \mathrm{Ar}$ and $\mathrm{U} / \mathrm{Pb}$ ages mentioned above. On the other hand, the eroded morphology of the volcano may be due to the effect of the four faults that cut it, besides the western scar due to the sector collapse. In recent works, Ortuño et al. (2015) and Lacan et al. (2017) do not report any pumice deposits of $<30 \mathrm{ka}$ in paleoseismological trenches (Fig. 1c). These points, in any case do not correspond to the dispersion trend of the SMP eruption (Fig. 1c). The only deposits in trenches with ages between 30 and $23 \mathrm{ka}$, were reported SE of the town of Acambay (Langridge et al., 2000; Fig. 1c) with an age of $<30 \mathrm{ka}$. This would be consistent with the dispersion trend of the SMP 

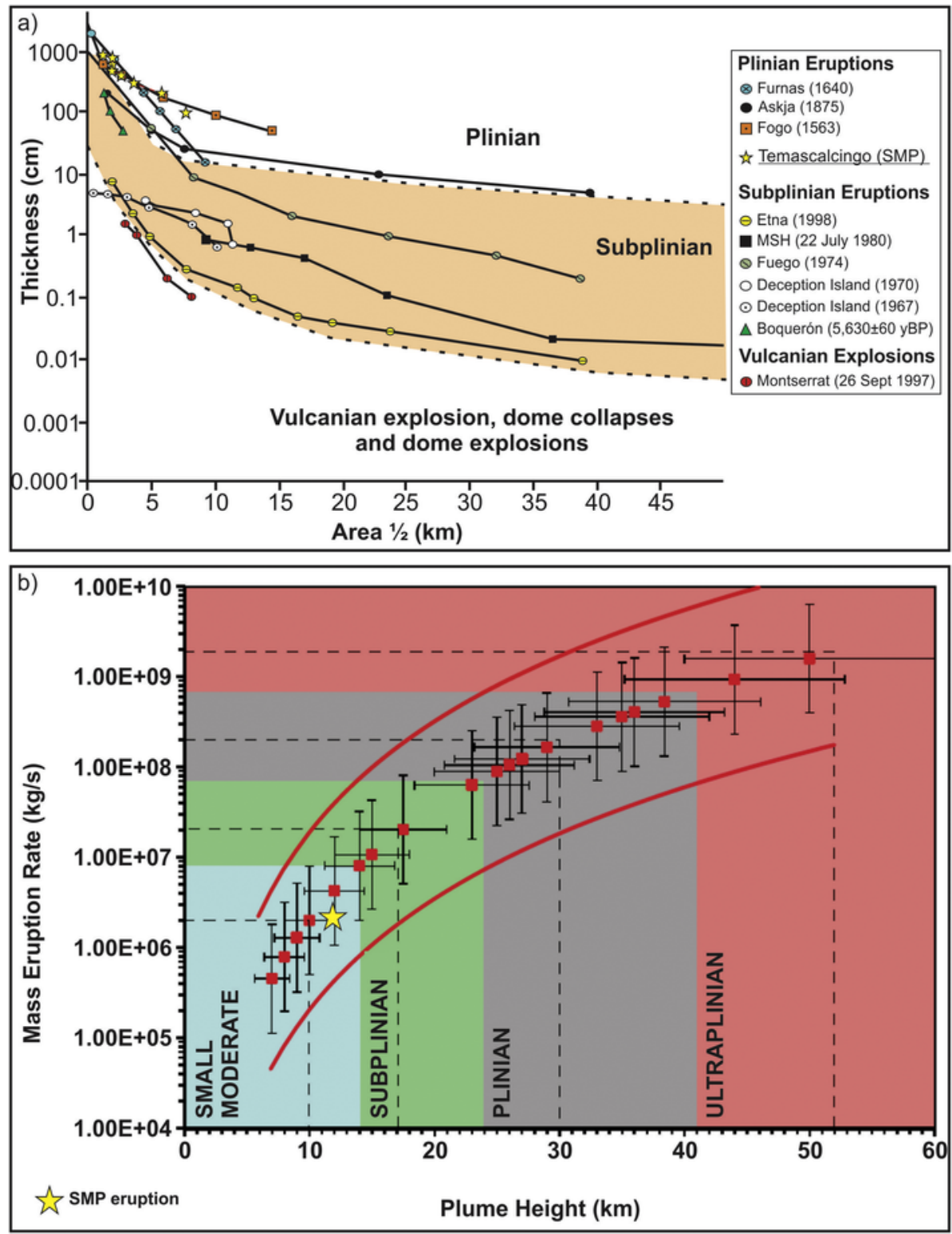

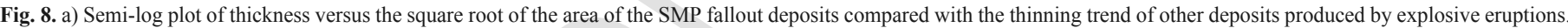

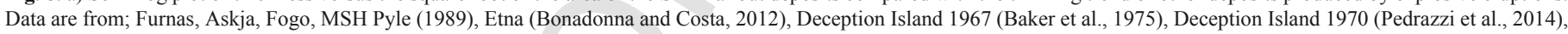

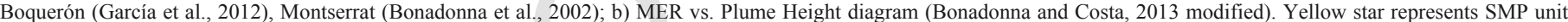
(present study). (For interpretation of the references to colour in this figure legend, the reader is referred to the web version of this article.)

deposits and with the same age reported for both paleosols underneath the SMP at Temas-1 site (Figs. 2 and 3b,c), dated respectively at 30 and $25 \mathrm{ka}$.

In any case, we might suggest that soil formation and preservation at the Temas-1 site might have been influenced by local landscape dynamics. The deposition of the grain-supported SMP Unit might have allowed a subsequent percolation of younger organic matter inflecting the subsoils below the SMP Unit until rejuvenation. This would lead to an erroneous interpretation of the SMP deposit age.

The discrepancy between radiocarbon and radiometric ages for the SMP eruption and TV activity represents an important task to be solved for future hazard assessments in the Acambay graben, and it is at the moment a subject for a more in-depth study (Aguirre et al., in prep).

\subsection{SMP Unit and Cerritos Member}

Based on field evidence, it is possible to identify the SMP deposits as the last unit of the Cerritos Member, a sequence of three units belonging to the same eruption and that include the DAE and the Magdalena Flow (Fig. 10). Aguirre-Díaz et al. (2015) already summarised the volcanic evolution of the TV in a preliminary report and mentions that the landslide and blast event was apparently the last major event of the volcano. Based on isopach and isopleth maps of the SMP deposits (Fig. 5), the vent of the whole eruption should be located within the horseshoe-shaped depression at the western flank of the TV (Fig. 1c), and where the Temascalcingo town was built. The first avalanche deposit, the DAE Unit (Fig. 10b), was immediately followed by a lithic-rich pyroclastic flow deposit, the Mag- 

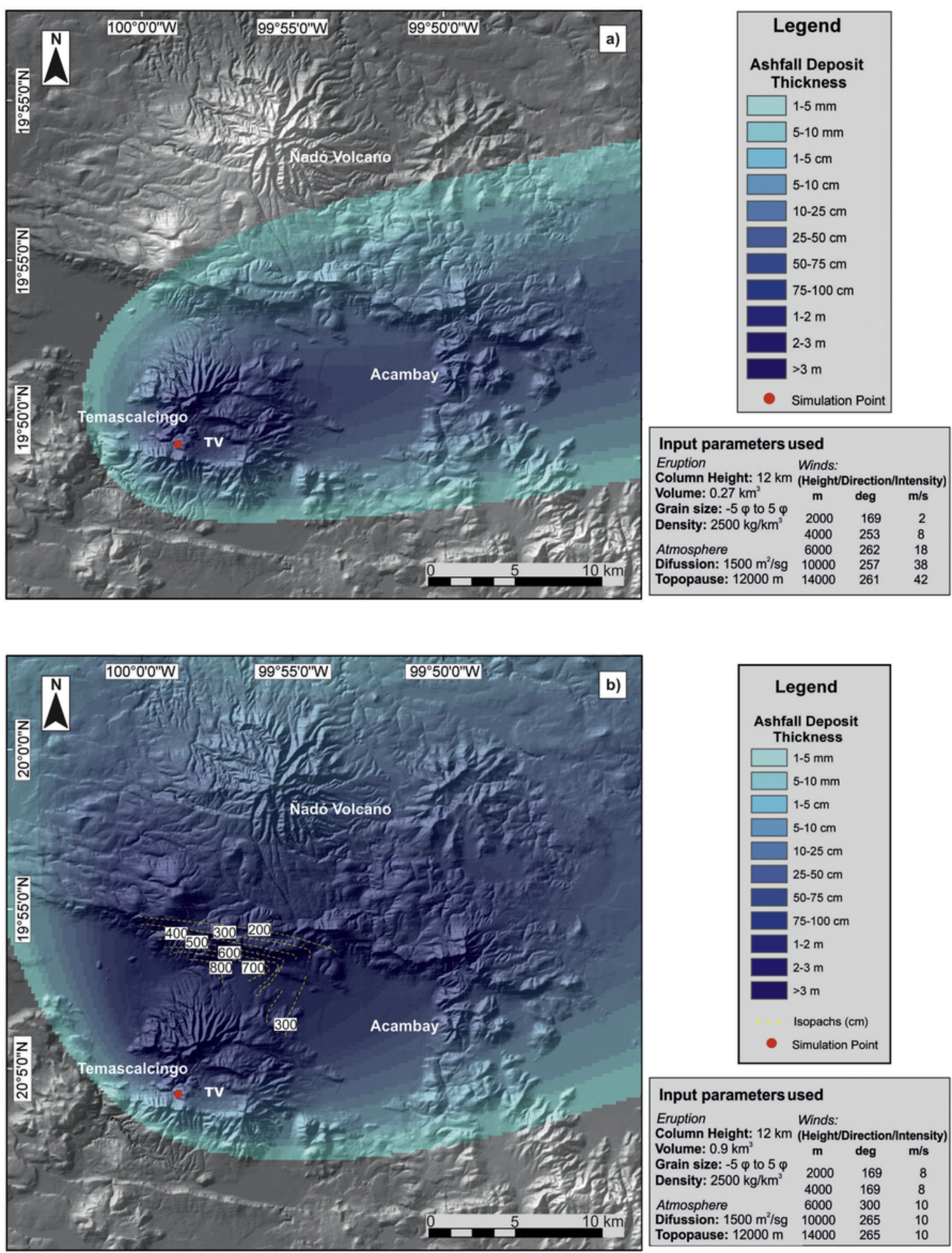

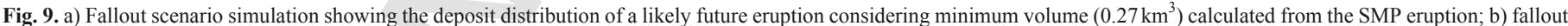
distribution that better fits the real remaining deposit in the field. Summary of input parameters used for the simulation are included in each figure.

dalena Unit (Fig. 10c), with its distribution very similar to that of the avalanche deposit (Roldán-Quintana et al., 2011). The occurrence of the SMP deposit in stratigraphic continuity, with no evidence of paleosols or sedimentary deposits, with the Magdalena Flow (Outcrops 54 and 60; Fig. 2 and Fig. 3i, j, k) suggests that all three units accumulated one after another in quick succession (Fig. 10d). The SMP might, therefore, be interpreted as the last phase of the landslide- blast-column event that ended with a subplinian type eruption (Fig. $10 \mathrm{~d}, \mathrm{e})$.

The inferred sequence of events that led to the deposition of the Cerritos Member is similar to that observed at Mount St. Helens in 1980 (Fisher, 1990; Druitt, 1992; Lipman and Mullineaux, 1981) or during the December 1997 eruption at Soufrière Hills volcano at Montserrat island, where the debris avalanche was followed by a 

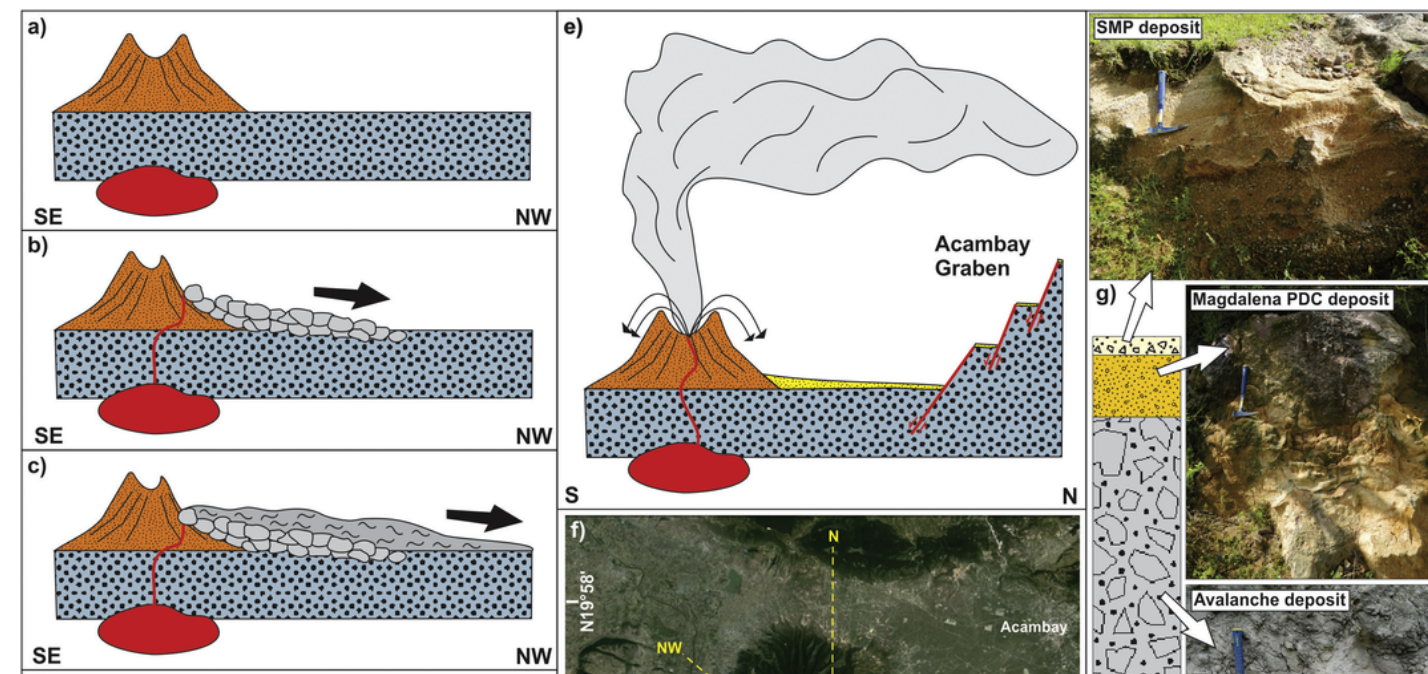

s
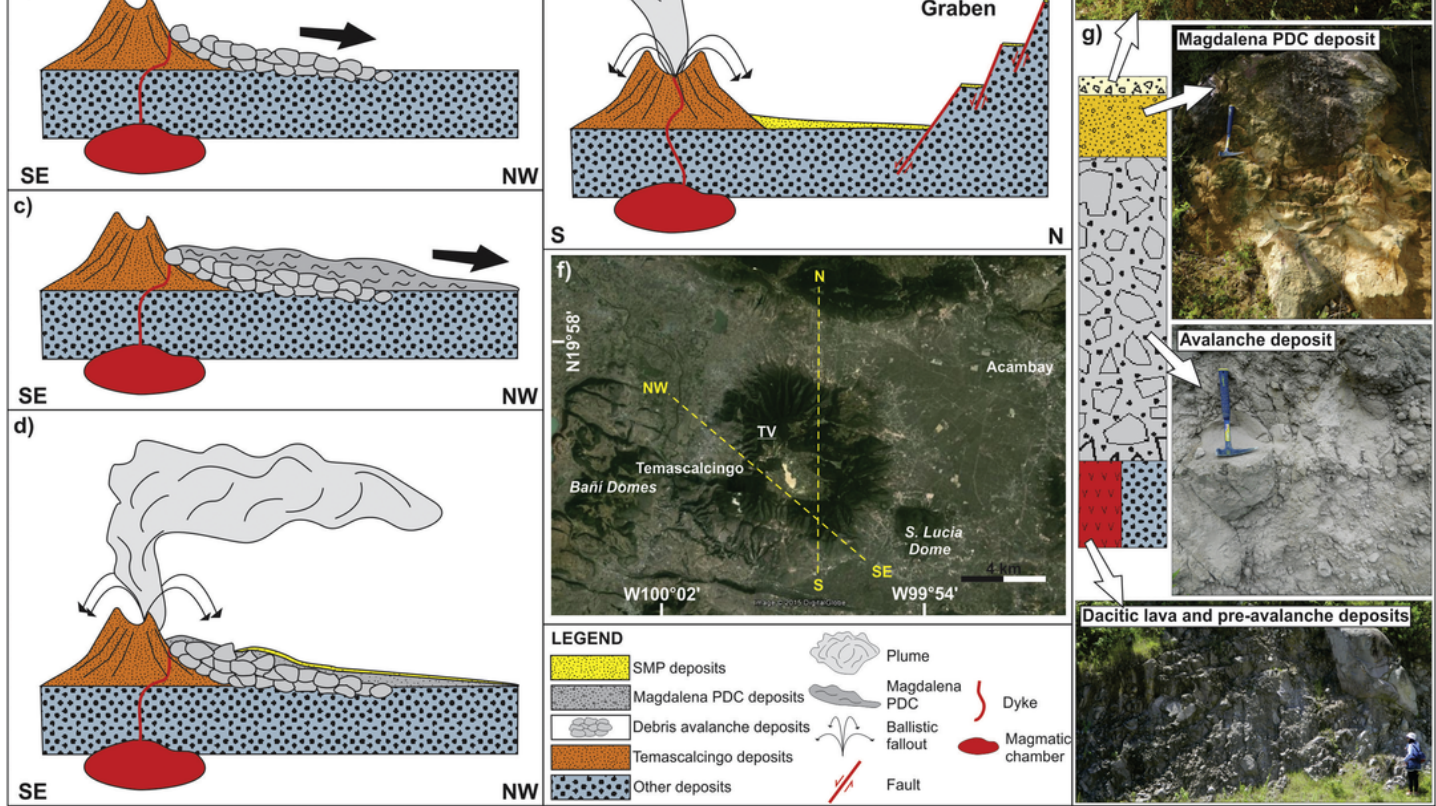

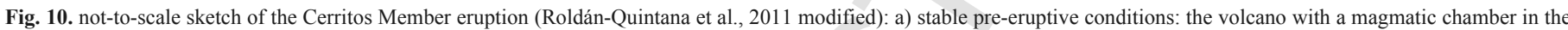

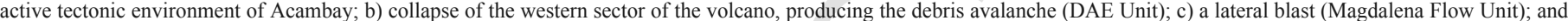
d-e) the final SMP eruption with a raising plume producing the fallout deposits of the SMP Unit.

dense pyroclastic flow of blocks and ash, as a result of the emplacement and destruction of a pressurized dome on top of the volcano (Young et al., 1998; Druitt and Kokelaar, 2002; Sparks et al., 2002; Woods et al., 2002). The same type of activity was described at the Jocotitlán volcano, near $\mathrm{TV}$, where the direction of the failure is probably related to the predominantly E-W tectonic trend of the area (Acambay graben) and the emplacement of the debris avalanche deposit was followed by explosive activity that formed pyroclastic surges and fall units, which ended with the formation of a dacitic dome (Siebe et al., 1992). Similarly, at the Popocatépetl volcano, the younger debris avalanche originated from Bezymianny-type activity that was accompanied by a lateral blast, followed by a plinian column yielding thick pumice fall and flow deposits (Siebe et al., 1995b). These types of sector collapse events are a common characteristic of various stratovolcanoes in the TMVB, including Nevado de Colima and Fuego, Nevado de Toluca, Las Derrumbadas and Pico de Orizaba, among many others (Capra et al., 2002).

Roldán-Quintana et al. (2011) in their model for the eruption suggest the formation of an over-pressurized dome due to magma intrusion with deformation and instability and collapse of the volcano on its western flank. This would be similar to Bezymianny in 1956 (Belousov, 1996; Belousov et al., 2007), or Mount St. Helens in 1980 (Druitt, 1992; Belousov, 1996). The authors suggest two hypotheses for the sector-collapse of the Temascalcingo volcano; first, the triggering of the eruption might be related to the movement of any of the faults affecting the TV, as it was the case for the Cardenas Cerritos avalanche (Norini et al., 2010). The actual amphitheatre is open to the west, and has a semi-rectangular shape and it could be a reflection of the E-W fault system affecting the volcano (Sunyé-Puchol et al.,
2012) and the whole Acambay area (Suter et al., 1995a, 1995b; Lacan et al., 2013; Langridge et al., 2013; Suñé-Puchol et al., 2013; Ortuño et al., 2015, 2018; Lacan et al., 2017, 2018). The tectonic setting of the volcano may influence the direction of collapse (Siebert, 1984), and in some cases faulting may trigger collapse (McGuire, 1996). In any case, according to Roldán-Quintana et al. (2011), the actual morphology of the amphitheatre might as well be the result of a first collapse under the influence of the local tectonic system, subsequently affected by E-W faults that cut the volcano, giving the actual elongated $\mathrm{E}-\mathrm{W}$ rectangular shape. In addition, the mass of the volcano can induce isostatic pressure, compaction, and deformation, leading directly to collapse (Borgia et al., 1992; De Vries and Borgia, 1996). This is the case for the example of the 7500B.P. eruption at Socompa Volcano in northern Chile (Kelfoun and Druitt, 2005), with the reactivation of local basement faults induced by the growth of the volcano edifice. As proposed by Capra et al. (2002), structural factors may predispose volcanoes to fail in a particular direction. From the studied cases within the TMVB, the preferred directions of failure are southwards and north-eastwards, with some deviations from those principal trends, mainly in the E-W direction, Capra et al. (2002), as is the case at TV.

Roldán-Quintana et al. (2011) in their discussion about the sector-collapse also take into account the possibility of an earthquake as the triggering mechanism. Several studies have been carried out in the area demonstrating that large seismic events can be generated by faults in the TMVB (Suter et al., 1995a, 1995b, 1996; Langridge et al., 2000; Ortuño et al., 2012, 2015, 2018; Sunyé-Puchol et al., 2015; Lacan et al., 2017, 2018) and, therefore, the relationship between 
seismic events and volcanic eruptions in the Acambay graben cannot be ruled out.

\section{Conclusion}

The San Mateo Pumice (SMP) fallout deposit originated from a $12 \mathrm{~km}$ high plume ( $14 \mathrm{~km}$ above sea level) possibly related to the partial collapse of the eastern side of the volcano that lead at the beginning to the emplacement of a debris avalanche and a PDC. Stratigraphic data suggest a highly explosive eruption of VEI 4, with a $\mathrm{NE}$ trending dispersion over an area of at least $100 \mathrm{~km}^{2}$. Calculations resulted in a volume of $0.27 \mathrm{~km}^{3}$, a peak mass eruption rate of $6.7 \times 10^{6} \mathrm{~kg} / \mathrm{s}$ and an estimated duration of about $9 \mathrm{~h}$. On the scale of Pyle (2000), the associated magnitude is 4.2 , and the intensity is 9.8 . Radiocarbon and radiometric dating show discrepancy, thus highlighting the importance of conducting a more accurate reconstruction of the whole geological history of the TV and surrounding volcanoes.

Supplementary data to this article can be found online at https:// doi.org/10.1016/j.jvolgeores.2018.10.007.

\section{Uncited reference}

\section{Ramirez-Herrera, 1998}

\section{Acknowledgments}

This research has been funded by a grant from the Universidad Nacional Autónoma de México (UNAM) DGAPA-PAPIIT IN-104615. DP is grateful for his postdoctoral grant from UNAM CJIC/CTIC/ 0954/2014. The authors thank the Town Halls of Temascalcingo and Acambay for their help and logistic support. The manuscript was greatly improved by comments from Dr. Pierre Lacan and Dr. María Ortuño regarding the tectonics of the Acambay graben. We appreciate the $\mathrm{U} / \mathrm{Th}$ and $\mathrm{U} / \mathrm{Pb}$ analyses supervised by Dr. Pablo Bernal at the Centro de Geociencias, UNAM. We also acknowledge the thin section descriptions by Juan T. Vasquez from the Centro de Geociencia, UNAM, XRF analyses by Rufino Lozano Santacruz and Patricia Girón García from the Instituto de Geología, UNAM, and sample preparation and granulometric analyses by undergrad students Ricardo Molina Bustos, Karina A. Rodríguez García, and Juana G. Hernández Trejo. We thank the Editor-in-Chief Prof. Joan Martí, one anonymous reviewer and Dr. Damiano Sarocchi for their constructive and supportive comments that significantly helped us to improve the manuscript. English text was corrected by Dr. Grant George Buffett of Terranova Scientific.

\section{References}

Aguilar, V., Verma, S., 1987. Composición química (elementos mayores) de los magmas en el Cinturón Volcánico Mexicano. Geofis. Int. 26 (2).

Aguirre-Díaz, G.J., 1993. The Amealco Caldera, Queretaro, Mexico: Geology, Geochronology, Geochemistry, and Comparison with Other Silicic Centers of the Mexican Volcanic Belt.

Aguirre-Díaz, G.d.J., 1995. La toba Amealco y su correlación con la formación Las Américas a través del graben de Acambay, estados de México, Michoacán y Querétaro, Mexico. Revista mexicana de ciencias geológicas 12 (1), 3.

Aguirre-Díaz, G.d.J., 1996. Volcanic stratigraphy of the Amealco caldera and vicinity, Central Mexican Volcanic Belt. Revista Mexicana de Ciencias Geológicas 13 (1), 2.

Aguirre-Díaz, G.J., López-Martínez, M., 2001. The Amazcala caldera, Queretaro, Mexico. Geology and geochronology. J. Volcanol. Geotherm. Res. 111 (1), 203-218.

Aguirre-Díaz, G.J., López-Martínez, M., 2009. Geologic evolution of the Donguinyó-Huichapan caldera complex, central Mexican Volcanic Belt, Mexico. J. Volcanol. Geotherm. Res. 179 (1), 133-148.

Aguirre-Díaz, G.J., McDowell, F.W., 2000. Volcanic evolution of the Amealco caldera, central Mexico. In: Delgado-Granados, H., Stock, J., Aguirre-Díaz,
G.J. (Eds.), Cenozoic Tectonics and Volcanism of Mexico. Geological Society of America Special Paper Vol. 334, pp. 167-178. https://doi.org/10.1130/ 0-8137-2334-5.179, (ISSN: 0072-1077).

Aguirre-Díaz, G., Ferrari, L., Nelson, S., Carrasco-Núñez, G., López-Martínez, M., Urrutia-Fucugauchi, J., 1998. El Cinturón volcánico Mexicano: un proyecto multidisciplinario. GEOS, Unión Geofísica Mexicana, AC, 131-138.

Aguirre-Diaz, G., Urrutia-Fucugauchi, J., Soler-Arechalde, A.M., McDowell, F.W., 2000. Stratigraphy, K-Ar ages, and magnetostratigraphy of the Acambay graben, central Mexican Volcanic Belt. In: Special Papers-Geological Society of America. pp. $167-178$

Aguirre-Díaz, G.J., Nieto-Obregón, J., Zúñiga, F.R., 2005. Seismogenic basin and range and intra-arc normal faulting in the central Mexican Volcanic Belt, Querétaro, México. Geol. J. 40 (2), 215-243.

Aguirre-Díaz, G.J., del Carmen Jaimes-Viera, M., Nieto-Obregón, J., 2006. The Valle de Bravo Volcanic Field: geology and geomorphometric parameters of a Quaternary monogenetic field at the front of the Mexican Volcanic Belt. Geol. Soc. Am. Spec. Pap. 402, 139-154

Aguirre-Díaz, G.J., Pedrazzi, D., Sunye-Puchol, I., Roldán-Quintana, J., Lacan, P., 2015. The Temascalcingo volcano, Estado de México: Main volcanic phases of a stratovolcano in the Acambay Graben. Reunión Anual Unión Geofísica Mexicana 2015 Vol. 35, Geos, ((No. 1): Abstract VUL-0208).

Baker, P.E., McReath, I., Harvey, M.R., Roobol, M.J., Davies, T.G., 1975. The geology of the South Shetland Islands. V. Volcanic evolution of Deception Island. Brit. Antarct. Surv. 78-81

Balbas, A.M., 2016. Application of Cosmogenic Nuclides and Argon Geochronology to Paleoclimate, Paleomagnetism, and Paleohydrology. Oregon State University, Corvallis, Oregon.

Belousov, A., 1996. Deposits of the 30 March 1956 directed blast at Bezymianny volcano, Kamchatka, Russia. Bull. Volcanol. 57 (8), 649-662.

Belousov, A., Voight, B., Belousova, M., 2007. Directed blasts and blast-generated pyroclastic density currents: a comparison of the Bezymianny 1956, Mount St Helens 1980, and Soufrière Hills, Montserrat 1997 eruptions and deposits. Bull. Volcanol. 69 (7), 701.

Bernal, J.P., Lozano-Santacruz, R., 2005. Characterization of a new set of eight geochemical reference materials for XRF major and trace element analysis. Revista Mexicana de Ciencias Geológicas 22 (3), 329-344.

Bernal, J.P., Solari, L.A., Gómez-Tuena, A., Ortega-Obregón, C., Mori, L., Vega-González, M., Espinosa-Arbeláez, D.G., 2014. In-situ 230Th/U dating of Quaternary zircons using LA-MCICPMS. Quat. Geochronol. 23, 46-55.

Bonadonna, C., Costa, A., 2012. Estimating the volume of tephra deposits: a new simple strategy. Geology 40 (5), 415-418.

Bonadonna, C., Costa, A., 2013. Plume height, volume, and classification of explosive volcanic eruptions based on the Weibull function. Bull. Volcanol. 75 (8), 1-19.

Bonadonna, C., Houghton, B.F., 2005. Total grain-size distribution and volume of tephra-fall deposits. Bull. Volcanol. 67 (5), 441-456.

Bonadonna, C., Macedonio, G., Sparks, R.S.J., 2002. Numerical modelling of tephra fallout associated with dome collapses and vulcanian explosions: application to hazard assessment on Montserrat. In: Druitt, T.H., Kokelaar, B.P. (Eds.), The Eruption of Soufrière Hills Volcano, Montserrat, from 1995 to 1999. Geological Society of London, London, pp. 517-537.

Borgia, A., Ferrarit, L., Pasquarè, G., 1992. Importance of gravitational spreading in the tectonic and volcanic evolution of Mount Etna. Nature 357, 6375.

Capra, L., Macias, J.L., 2000. Pleistocene cohesive debris flows at Nevado de Toluca Volcano, central Mexico. J. Volcanol. Geotherm. Res. 102 (1-2), 149-167.

Capra, L., Macias, J., Scott, K., Abrams, M., Garduño-Monroy, V., 2002. Debris avalanches and debris flows transformed from collapses in the Trans-Mexican Volcanic Belt, Mexico-behavior, and implications for hazard assessment. J. Volcanol. Geotherm. Res. 113 (1), 81-110.

Carey, S., Sparks, R.S.J., 1986. Quantitative models of the fallout and dispersal of tephra from volcanic eruption columns. Bull. Volcanol. 48 (2-3), 109-125.

Carrasco-Núñez, G., 1999. Holocene block-and-ash flows from summit dome activity of Citlaltépetl volcano, Eastern Mexico. J. Volcanol. Geotherm. Res. 88 (1), 47-66.

Carrasco-Núñez, G., Gomez-Tuena, A., 1997. Volcanogenic sedimentation around Citlaltépetl volcano (Pico de Orizaba) and surroundings, Veracruz, Mexico. In: Magmatism and Tectonics in the Central and Northwestern México-a Selection of the 1997 IAVCEI General Assembly Excursions. pp. 131-151.

Carrasco-Núñez, G., Vallance, J.W., Rose, W.I., 1993. A voluminous avalanche-induced lahar from Citlaltépetl volcano, Mexico: implications for hazard assessment. J. Volcanol. Geotherm. Res. 59 (1), 35-46.

Carrasco-Nuñez, G., Hernández, J., De León, L., Dávila, P., Norini, G., Bernal, J.P., Jicha, B., Navarro, M., López-Quiroz, P., 2017. Geologic map of Los Humeros volcanic complex and geothermal field, eastern Trans-Mexican Volcanic Belt. Terra Digitalis 1 (2).

Cerca Martinez, L.M., Aguirre Diaz, G.D.J., Lopez Martinez, M., 2000. The geologic evolution of the Southern Sierra de Guanajuato, Mexico: a documented example of the transition from the Sierra Madre Occidental to the Mexican Volcanic Belt. Int. Geol. Rev. 42 (2), 131-151. 
Daggitt, M.L., Mather, T.A., Pyle, D.M., Page, S., 2014. AshCalc-a new tool for the comparison of the exponential, power-law and Weibull models of tephra deposition. J. Appl. Volcanol. 3 (1), 1-8.

De Cserna, Z., 1989. An outline of the geology of Mexico. In: The Geology of North America-An Overview. Volume A, The Geological Society of America, Boulder, pp. 233-264.

De Vries, B.V.W., Borgia, A., 1996. The role of basement in volcano deformation. Geol. Soc. Lond., Spec. Publ. 110 (1), 95-110.

Demant, A., 1978. Características del Eje Neovolcánico Transmexicano y sus problemas de interpretación. Revista mexicana de ciencias geológicas 2 (2), 172-187.

Druitt, T.H., 1992. Emplacement of the 18 May 1980 lateral blast deposit ENE of Mount St. Helens, Washington. Bull. Volcanol. 54 (7), 554-572.

Druitt, T.H., Kokelaar, B.P., 2002. The Eruption of Soufrière Hills Volcano, Montserrat, from 1995 to 1999. Geological Society of London.

Felpeto, A., Martí, J., Ortiz, R., 2007. Automatic GIS-based system for volcanic hazard assessment. J. Volcanol. Geotherm. Res. 166, 106-116.

Ferrari, L., López-Martínez, M., Aguirre-Díaz, G., Carrasco-Núñez, G., 1999. Space-time patterns of Cenozoic arc volcanism in central Mexico: from the Sierra Madre Occidental to the Mexican Volcanic Belt. Geology 27 (4), 303-306.

Ferrari, L., Orozco-Esquivel, T., Manea, V., Manea, M., 2012. The dynamic history of the Trans-Mexican Volcanic Belt and the Mexico subduction zone. Tectonophysics 522, 122-149.

Ferriz, H., Mahood, G.A., 1987. Strong compositional zonation in a silicic magmatic system: Los Humeros, Mexican Neovolcanic Belt. J. Petrol. 28 (1), 171-209.

Fisher, R.V., 1990. Transport and deposition of a pyroclastic surge across an area of high relief: the 18 May 1980 eruption of Mount St. Helens, Washington. Geol. Soc. Am. Bull. 102 (8), 1038-1054.

García, O., Bonadonna, C., Martí, J., Pioli, L., 2012. The 5,660yBP Boquerón explosive eruption, Teide-Pico Viejo complex, Tenerife. Bull. Volcanol. 74 (9), 2037-2050

Garduño-Monroy, V., Pérez-Lopez, R., Israde-Alcantara, I., Rodríguez-Pascua, M., Szynkaruk, E., Hernández-Madrigal, V., García-Zepeda, M., Corona-Chávez, P. Ostroumov, M., Medina-Vega, V., 2009. Paleoseismology of the southwestern Morelia-Acambay fault system, central Mexico. Geofísica internacional 48 (3), 319-335.

Hasenaka, T., 1994. Size, distribution, and magma output rate for shield volcanoes of the Michoacán-Guanajuato volcanic field, Central Mexico. J. Volcanol. Geotherm. Res. 63 (1), 13-31.

Hasenaka, T., Carmichael, I.S., 1985. The cinder cones of Michoacán-Guanajuato, central Mexico: their age, volume and distribution, and magma discharge rate. J. Volcanol. Geotherm. Res. 25 (1), 105-124.

Hoskuldsson, A., Robin, C., 1993. Late Pleistocene to Holocene eruptive activity of Pico de Orizaba, Eastern Mexico. Bull. Volcanol. 55 (8), 571-587.

Houghton, B., Carey, R.J., 2015. Pyroclastic fall deposits. In: The Encyclopedia of Volcanoes, second edition, pp. 599-616.

Inman, D., 1952. Measures for describing the size distribution of sediments. J. Sediment. Petrol. 22, 125-145.

Johnson, C.A., Harrison, C.G.A., 1990. Neotectonics in central Mexico. Phys. Earth Planet. Inter. 64 (2-4), 187-210.

Kelfoun, K., Druitt, T.H., 2005. Numerical modeling of the emplacement of Socompa rock avalanche, Chile. J. Geophys. Res. Solid Earth 110 (B12).

Komorowski, J., Navarro, C., Cortes, A., Siebe, C., 1994. The repetitive collapsing nature of Colima volcanoes (Mexico), Problems related to the distinction of multiple deposits and the interpretation of $14 \mathrm{C}$ ages with implications for future hazards. In Colima Volcano Fourth International Meeting, Mexico. pp. 12-18.

Komorowski, J., Navarro, C., Cortes, A., Saucedo, R., Gavilanes, J., Siebe, C., Espíndola, J., Rodriguez-Elizarrarás, S., 1997. The Colima Volcanic Complex. Field Guide. Vol. 3.

Koppers, A.A.P., 2002. ArArCALC—Software for 40Ar/39Ar age calculations. Comput. Geosci. 28 (5), 605-619.

Koppers, A.A.P., Gowen, M.D., Colwell, L.E., Gee, J.S., Lonsdale, P.F., Mahoney, J.J., Duncan, R.A., 2011. New 40Ar/39Ar age progression for the Louisville hot spot trail and implications for inter-hot spot motion. Geochem. Geophys. Geosyst. 12 .

Kuiper, K.F., Deino, A., Hilgen, F.J., Krijgsman, W., Renne, P.R., Wijbrans, J.R., 2008. Synchronizing rock clocks of Earth history. Science 320, 500-504.

Lacan, P., Orduño, M., Perea, H., Baize, S., Audin, L., Aguirre, G., Zúñiga, F.R., 2013. Upper Pleistocene to Holocene Earthquakes Recorded at the Western Termination of the Venta de Bravo Fault System, Acambay Graben (central Mexico). Seismic Hazard, Critical Facilities and Slow Active Faults. 9-14

Lacan, P., Ortuño, M., Audin, L., Perea, H., Baize, S., Aguirre-Díaz, G., Zúñiga, F.R. 2017. Historical and prehistorical earthquakes recorded along the Venta de Bravo Fault System, Acambay Graben (Central Mexico). J. Sediment. Geol. 365, 62-77.

Lacan, P., Ortuño, M., Audin, L., Perea, H., Baize, S., Aguirre-Díaz, G., Zúñiga, F.R., 2018. Sedimentary evidence of historical and prehistorical earthquakes along the Venta de Bravo Fault System, Acambay Graben (Central Mexico). Sediment. Geol. 365, 62-77.

Langridge, R.M., Weldon, R.J., Moya, J.C., Suárez, G., 2000. Paleoseismology of the 1912 Acambay earthquake and the Acambay-Tixmadejé fault, Trans-Mexican volcanic belt. J. Geophys. Res. Solid Earth 105 (B2), 3019-3037.

Langridge, R.M., Persaud, M., Zúñiga, F.R., Díaz, G.d.J.A., Pérez, P.V., Lacan, P., 2013. Preliminary paleoseismic results from the Pastores fault and its role in the seismic hazard of the Acambay graben, Trans-Mexican Volcanic Belt, Mexico. Revista Mexicana de Ciencias Geológicas 30 (3), 463-481.

Le Bas, M.J., Le Maitre, R., Streckeisen, A., Zanettin, B., 1986. A chemical classification of volcanic rocks based on the total alkali-silica diagram. J. Petrol. 27 (3), 745-750.

Lipman, P.W., Mullineaux, D.R., 1981. The 1980 Eruptions of Mount St. Helens, Washington. US Dept. of the Interior, US Geological Survey.

Lozano-Velazquez, L., Carrasco-Núñez, G., 1997. Laharic Sequences at the Sothwestern Flank of Popocatépetl Volcano, Mexico. IAVCEI General Assembly, Puerto Vallarta, 95

Ludwig, K., 2008. Manual for Isoplot 3.7. 4, Berkeley Geochronology Center, 77, Special Publication.

Luhr, J.F., Carmichael, I.S., 1980. The colima volcanic complex, Mexico. Contrib. Mineral. Petrol. 71 (4), 343-372.

Luhr, J.F., Prestegaard, K.L., 1988. Caldera formation at Volcán Colima, Mexico, by a large holocene volcanic debris avalanche. J. Volcanol. Geotherm. Res. 35 (4), 335-348.

Macías, J.L., García, P., Arce, J., Siebe, C., Espíndola, J., Komorowski, J., Scott, K., 1997. Late Pleistocene-Holocene cataclysmic eruptions at Nevado de Toluca and Jocotitlan volcanoes, central Mexico. Brigham Young Univ. Geol. Stud. 42 (1), 493-528.

Mahood, G.A., 1980. Geological evolution of a Pleistocene rhyolitic center-Sierra la Primavera, Jalisco, Mexico. J. Volcanol. Geotherm. Res. 8 (2), 199-230.

Marshall, D.J., Mariano, A.N., 1988. Cathodoluminescence of Geological Materials. Taylor and Francis.

Martí, J., Groppelli, G., Brum Da Silveira, A., 2018. Volcanic stratigraphy: a review. J. Volcanol. Geotherm. Res. 357, 68-91.

Mastin, L., Guffanti, M., Servranckx, R., Webley, P., Barsotti, S., Dean, K., Durant, A., Ewert, J., Neri, A., Rose, W., 2009. A multidisciplinary effort to assign realistic source parameters to models of volcanic ash-cloud transport and dispersion during eruptions. J. Volcanol. Geotherm. Res. 186 (1), 10-21.

McGuire, W., 1996. Volcano instability: a review of contemporary themes. Geol. Soc. Lond., Spec. Publ. 110 (1), 1-23.

Nelson, S.A., 1980. Geology and petrology of Volcán Ceboruco, Nayarit, Mexico: summary. Geol. Soc. Am. Bull. 91 (11), 639-643.

Nelson, S.A., Hegre, J., 1990. Volcán Las Navajas, a Pliocene-Pleistocene trachyte peralkaline rhyolite volcano in the northwestern Mexican volcanic belt. Bull. Volcanol. 52 (3), 186-204.

Nelson, S.A., Livieres, R.A., 1986. Contemporaneous calc-alkaline and alkaline volcanism at Sanganguey Volcano, Nayarit, Mexico. Geol. Soc. Am. Bull. 97 (7), 798-808.

Newhall, C.G., Self, S., 1982. The volcanic explosivity index (VEI) an estimate of explosive magnitude for historical volcanism. J. Geophys. Res. Oceans 87 (C2), $1231-1238$.

Nixon, G.T., 1982. The relationship between Quaternary volcanism in central Mexico and the seismicity and structure of subducted ocean lithosphere. Geol. Soc. Am. Bull. 93 (6), 514-523.

Nixon, G.T., 1988. Petrology of the younger andesites and dacites of Iztaccíhuatl volcano, Mexico: II. Chemical stratigraphy, magma mixing, and the composition of basaltic magma influx. J. Petrol. 29 (2), 265-303

Norini, G., Capra, L., Borselli, L., Zuniga, F., Solari, L., Sarocchi, D., 2010. Large scale landslides triggered by Quaternary tectonics in the Acambay graben, Mexico. Earth Surf. Process. Landf. 35 (12), 1445-1455.

Ortuño, M., Zuñiga Dávila-Madrid, R., Corominas, A., Perea, H., Ramírez-Herrera, M.T., Stepanciková, P., Villamor, P., Norini, G., 2012. Paleoseismology of the Venta de Bravo, Tepuxtepec and Temascalcingo faults (Transmexican Volcanic Belt). Reunión anual Unión Geofísica Mexicana, A.C. del 28 de Octubre al 2 de Noviembre de 2012, Puerto Vallarta, Jalisco, México.

Ortuño, M., Zúñiga, F.R., Aguirre-Díaz, G.J., Carreón-Freyre, D., Cerca, M., Roverato, M., 2015. Holocene paleo-earthquakes recorded at the transfer zone of two major faults: the Pastores and Venta de Bravo faults (Trans-Mexican Volcanic Belt). Geosphere 11 (1), 160-184.

Ortuño, M., Corominas, O., Villamor, P., Zúñiga, R.F., Lacan, P., Aguirre-Díaz, G., Perea, H., Štěpančíková, S., Ramírez-Herrera, M.T., 2018. Evidence of recent ruptures in the central faults of the Acambay Graben (central Mexico). Geomorphology

Peccerillo, A., Taylor, S.R., 1976. Geochemistry of Eocene calc-alkaline volcanic rocks from the Kastamonu area, northern Turkey. Contrib. Mineral. Petrol.. 58 (1), 63-81.

Pedrazzi, D., Aguirre-Díaz, G., Bartolini, S., Martí, J., Geyer, A., 2014. The 1970 eruption on Deception Island (Antarctica): eruptive dynamics and implications for volcanic hazards. J. Geol. Soc. 171 (6), 765-778. 
Pyle, D., 1989. The thickness, volume and grainsize of tephra fall deposits. Bull. Volcanol. 51 (1), 1-15.

Pyle, D.L., 2000. Sizes of volcanic eruption. In: Sigurdsson, H., Houghton, B.F., McNutt, S.R., Rymer, H., Stix, J. (Eds.), Encyclopedia of Volcanoes. Academic Press pp. 263-269.

Ramírez-Herrera, M.T., 1994. Tectonic Geomorphology of the Acambay Graben, central Mexican Volcanic Belt. University of Edinburgh.

Ramirez-Herrera, M.T., 1998. Geomorphic assessment of active tectonics in the Acambay Graben, Mexican volcanic belt. Earth Surf. Process. Landf. 23 (4), 317-332.

Reimer, P.J., Bard, E., Bayliss, A., Beck, J.W., Blackwell, P.G., Bronk Ramsey, C., Buck, C.E., Cheng, H., Edwards, R.L., Friedrich, M., 2013. IntCal13 and Marine13 radiocarbon age calibration curves 0-50,000 years cal BP.

Robin, C., 1984. Le Volcan Popocatepetl (Mexique): structure, evolution pétrologique et risques. Bull. Volcanol. 47 (1), 1-23.

Robin, C., Boudal, C., 1987. A gigantic Bezymianny-type event at the beginning of modern volcan Popocatepetl. J. Volcanol. Geotherm. Res. 31 (1), 115-130.

Robin, C., Mossand, P., Camus, G., Cantagrel, J.-M., Gourgaud, A., Vincent, P.M., 1987. Eruptive history of the Colima volcanic complex (Mexico). J. Volcanol. Geotherm. Res. 31 (1), 99-113.

Robin, C., Komorowski, J.-C., Boudal, C., Mossand, P., 1990. Mixed-magma pyroclastic surge deposits associated with debris avalanche deposits at Colima volcanoes, Mexico. Bull. Volcanol. 52 (5), 391-403.

Roldán-Quintana, J., Aguirre-Díaz, G.d.J., Rodríguez-Castañeda, J.L., 2011. Depósito de avalancha de escombros del volcán Temascalcingo en el graben de Acambay, Estado de México. Revista mexicana de ciencias geológicas 28, 118-131.

Rossotti, A., Carrasco-Núñez, G., Rosi, M., Di Muro, A., 2006. Eruptive dynamics of the "Citlaltépetl pumice" at Citlaltépetl volcano, eastern Mexico. J. Volcanol. Geotherm. Res. 158 (3), 401-429.

Salinas, S., López-Blanco, J., 2010. Geomorphic assessment of the debris avalanche deposit from the Jocotitlán volcano, Central Mexico. Geomorphology 123 (1), $142-153$.

Sánchez-Rubio, G., 1984. Cenozoic Volcanism in the Toluca-Amealco Región, Central Mexico. Imperial College of Science and Technology, University of London, London, (Masters thesis).

Siebe, C., Komorowski, J.-C., Sheridan, M.F., 1992. Morphology and emplacement of an unusual debris-avalanche deposit at Jocotitlán volcano, Central Mexico. Bull. Volcanol. 54 (7), 573-589.

Siebe, C., Macias, J.L., Abrams, M., Rodriguez, S., Castro, R., Delgado, H., 1995. Quaternary Explosive Volcanism and Pyroclastic Deposits in East Central Mexico: Implications for Future Hazards, Guidebook of Geological Excursions: In Conjunction with the Annual Meeting of the Geological Society of America, New Orleans, Louisiana, November 6-9, 1995, Louisiana State University. Basin Research Institute. Center for Coastal Energy \& Environmental Resources, Baton Rouge, Louisiana, United States, 1-48

Siebe, C., Abrams, M., Macías, J., 1995. Derrumbes gigantes, depósitos de avalancha de escombros y edad del actual como del volcán Popocatépetl, Volcan Popocatepetl estudios realizados durante la crisis de 1994-1995. México, Comite Científico Asesor CENAPRED-UNAM, 195-220.

Siebe, C., Abrams, M., Macías, J.L., Obenholzner, J., 1996. Repeated volcanic disasters in prehispanic time at popocatepetl, central Mexico: past key to the future? Geology 24 (5), 399-402.

Siebe, C., Arana-Salinas, L., Abrams, M., 2005. Geology and radiocarbon ages of Tláloc, Tlacotenco, Cuauhtzin, Hijo del Cuauhtzin, Teuhtli, and Ocusacayo monogenetic volcanoes in the central part of the Sierra Chichinautzin, México. J. Volcanol. Geotherm. Res. 141 (3), 225-243.

Siebe, C., Macías, J.L., Aguirre-Díaz, G.J., 2006. Neogene-Quaternary Continental Margin Volcanism: A Perspective from Mexico. Geological Society of America

Siebert, L., 1984. Large volcanic debris avalanches: characteristics of source areas, deposits, and associated eruptions. J. Volcanol. Geotherm. Res. 22 (3-4), 163-197.

Sláma, J., Košler, J., Condon, D.J., Crowley, J.L., Gerdes, A., Hanchar, J.M., Horstwood, M.S.A., Morris, G.A., Nasdala, L., Norberg, N., Schaltegger, U., Schoene, B., Tubrett, M.N., Whitehouse, M.J., 2008. Plešovice zircon - a new natural reference material for $\mathrm{U}-\mathrm{Pb}$ and $\mathrm{Hf}$ isotopic microanalysis. Chem. Geol. 249, $1-35$

Sohn, Y.K., Chough, S.K., 1989. Depositional processes of the Suwolbong tuff ring, Cheju Island (Korea). Sedimentology 36 (5), 837-855.

Solari, L.A., Gómez-Tuena, A., Bernal, J.P., Pérez-Arvízu, O., Tanner, M., 2010. U-Pb zircon geochronology with an integrated LA-ICP-MS microanalytical workstation: achievements in precision and accuracy. Geostand. Geoanal. Res. 34, 5-18.

Sparks, R., Barclay, J., Calder, E., Herd, R., Komorowski, J., Luckett, R., Norton, G., Ritchie, L., Voight, B., Woods, A., 2002. Generation of a debris avalanche and violent pyroclastic density current on 26 December (Boxing Day) 1997 at Soufriere Hills Volcano, Montserrat. Geol. Soc. Lond. Mem. 21 (1), 409-434.
Stoopes, G.R., Sheridan, M.F., 1992. Giant debris avalanches from the Colima Volcanic complex, Mexico: implications for long-runout landslides $(>100 \mathrm{~km})$ and hazard assessment. Geology 20 (4), 299-302.

Suárez, G., Singh, S., 1986. Tectonic interpretation of the Trans-Mexican Volcanic Belt-discussion. Tectonophysics 127 (1), 155-158.

Sulpizio, R., Mele, D., Dellino, P., Volpe, L., 2005. A complex, Subplinian-type eruption from low-viscosity, phonolitic to tephri-phonolitic magma: the AD 472 (Pollena) eruption of Somma-Vesuvius, Italy. Bull. Volcanol. 67 (8), 743-767.

Suñé-Puchol, I., Lacan, P., Villamor, P., Ortuño, M., Aguirre-Díaz, G., Audin, L., Lawton, T., Langridge, R., Zúñiga, R., 2013. Paleoseismological study of the San Mateo fault, Acambay Graben (México). In: 4th International INQUA Meeting on Paleoseismology, Active Tectonics and Archeoseismology (PATA), 9-14 October 2013, Aachen, Germany.

Sunyé-Puchol, I., Lacan, P., Zuñiga, R., Cerca, M., Aguirre-Díaz, G., Ortuño, M. 2012. Analogue model of the San Pedro Volcano in the Acambay Graben (México). 3rd INQUA-IGCP-567 International Workshop on Active Tectonics, Paleoseismology and Archaeoseismology, Morelia, Mexico.

Sunyé-Puchol, I., Lacan, P., Ortuño, M., Villamor, P., Audin, L., Zúñiga, F.R., Langridge, R.M., de Jesús Aguirre-Díaz, G., Lawton, T.F., 2015. La falla San Mateo: nuevas evidencias paleosismológicas de fallamiento activo en el graben de Acambay, México. Revista Mexicana de Ciencias Geológicas 32 (3), 361-376.

Suter, M., Aguirre, G., Siebe, C., Quintero, O., Komorowski, J., 1991. Volcanism and Active Faulting in the Central Part of the Trans-Mexican Volcanic Belt, Mexico, Geological Excursions in Southern California and Mexico, Guidebook, Annual Meeting of the Geological Society of America, San Diego, California, October. $21-24$

Suter, M., Quintero, O., Johnson, C.A., 1992. Active faults and state of stress in the central part of the Trans-Mexican Volcanic Belt, Mexico 1. The Venta de Bravo Fault. J. Geophys. Res. Solid Earth 97 (B8), 11983-11993.

Suter, M., Quintero-Legorreta, O., López-Martinez, M., Aguirre-Díaz, G., Farrar, E., 1995. The Acambay graben: active intraarc extension in the trans-Mexican volcanic belt, Mexico. Tectonics 14 (6), 1245-1262.

Suter, M., Carrillo Martínez, M., López Martínez, M., Farrar, E., 1995. The Aljibes half-graben - active extension at the boundary between the trans-Mexican volcanic belt and the Basin and Range Province, Mexico. Geol. Soc. Am. Bull. 107 (6), 627-641.

Suter, M., Carrillo-Martínez, M., Quintero-Legorreta, O., 1996. Macroseismic study of shallow earthquakes in the central and eastern parts of the trans-Mexican volcanic belt, Mexico. Bull. Seismol. Soc. Am. 86 (6), 1952-1963.

Suter, M., Martínez, M.L., Legorreta, O.Q., Martínez, M.C., 2001. Quaternary intra-arc extension in the central Trans-Mexican volcanic belt. Geol. Soc. Am. Bull. 113 (6), 693-703.

Suzuki, T., 1983. A theoretical model for dispersion of Tephra. In: Shimozuru, D., Yokoyama, I. (Eds.), Arc Volcanism, Physics and Tectonics. Terra Scientific Publishing Company, Tokyo.

Valdéz-Moreno, G., Aguirre-Díaz, G., López-Martínez, M., 1998. El Volcán La Joya, estados de Quéretaro y Guanajuato: un estratovolcán Miocénico del Cinturón volcánico Mexicano. Revista Mexicana de Ciencias Geológicas 15 (2), 181-197.

Verma, S.P., Carrasco-Núñez, G., 2003. Reappraisal of the geology and geochemistry of Volcán Zamorano, central Mexico: implications for discriminating the Sierra Madre Occidental and Mexican volcanic belt provinces. Int. Geol. Rev. 45 (8), 724-752.

Walker, G.P.L., 1971. Grain size characteristics of pyroclastic deposits. J. Geol. 79 (6), 696-714.

Wallace, P.J., Carmichael, I.S., 1994. Petrology of Volcán Tequila, Jalisco, Mexico: disequilibrium phenocryst assemblages and evolution of the subvolcanic magma system. Contrib. Mineral. Petrol. 117 (4), 345-361.

White, J.D.L., Houghton, B.F., 2006. Primary volcaniclastic rocks. Geology 34 (8), $677-680$.

Wilson, L., Walker, G., 1987. Explosive volcanic eruptions-VI. Ejecta dispersal in plinian eruptions: the control of eruption conditions and atmospheric properties Geophys. J. Int. 89 (2), 657-679.

Woods, A., Sparks, R., Ritchie, L., Batey, J., Gladstone, C., Bursik, M., 2002. The explosive decompression of a pressurized volcanic dome: the 26 December $1997 \mathrm{col}-$ lapse and explosion of Soufrière Hills Volcano, Montserrat. Geol. Soc. Lond. Mem. 21 (1), 457-465.

Young, S.R., Sparks, R.S.J., Aspinall, W.P., Lynch, L.L., Miller, A.D., Robertson, R.E., Shepherd, J.B., 1998. Overview of the eruption of Soufriere Hills volcano, Montserrat, 18 July 1995 to December 1997. Geophys. Res. Lett. 25 (18), 3389-3392.

A binocular microscope was used to determine the main petrographic and textural characteristics of the juvenile components, and to identify the mineralogy and general composition of the studied deposits. All the analyses were performed in the Physical Volcanology Laboratory of Centro de Geociencias, Universidad Nacional Autónoma de México, at Juriquilla-Querétaro (Mexico). The most 
representative levels of each stratigraphic unit were sampled and analysed (94 samples in total- see Fig. 2 and Supplementary Materials 1 and 2 for grain-size distribution and componentry. Grain-size analysis was performed by dry sieving at 1 phi $(\Phi)$ intervals with sieves having aperture sizes ranging from 32 to $1 / 32 \mathrm{~mm}(-5 \Phi$ to $5 \Phi)$. The weight percentages of the sieved fractions were calculated and then plotted as cumulative curves to give the grain-size distribution. Grain-size data were used to define the median diameter (Md $\Phi$ ) and sorting $(\sigma \Phi)$ (Inman, 1952). The proportion of juveniles from -5 $\Phi$ to $0 \Phi$ was defined by hand picking, and from $0 \Phi$ to $1 \Phi$ using the binocular microscope and image analysis techniques (e.g., ImageJ software). This method allowed the different components of each particle-size class to be identified (Supplementary Material 1).

Lithic clasts predominantly consist of dacitic lava fragments of TV and juvenile clasts consisting of poorly vesiculated, crystal-poor, angular-to-subangular, yellow-to-grey pumice lapilli (Fig. 2). Lithics content is mostly constant in all deposits with values around 5-7\% wt. (Supplementary Material 1) increasing only in some levels reaching around $15-17 \%$ (e.g., samples Temas-1E, Temas4-A, Temas4-C, Temas22-D, Temas36-B, Temas54-B, and Temas61-BSupplementary Material 1).

The eruption was characterised by repeated clearing of the conduit, as deduced by the presence of dacitic lava lithic-rich layers. Indeed, the lithic content is nearly constant in most deposits with values $5-7 \mathrm{wt} \%$ (Supplementary Material 1), but at some levels, there is an increase to $15-17 \mathrm{wt} \%$ (e.g., samples Temas-1E, Temas4-A, Temas4-C, Temas22-D, Temas36-B, Temas54-B, and Temas61-BSupplementary Material 1), resulting in increased density of the erupting mixture (Sulpizio et al., 2005). These lithics belong to the volcano substrate as suggested by Roldán-Quintana et al. (2011), who identified them in the Magdalena Flow, the predominance of a single type of lithic of porphyritic dacite.
The following are the supplementary data related to this article.

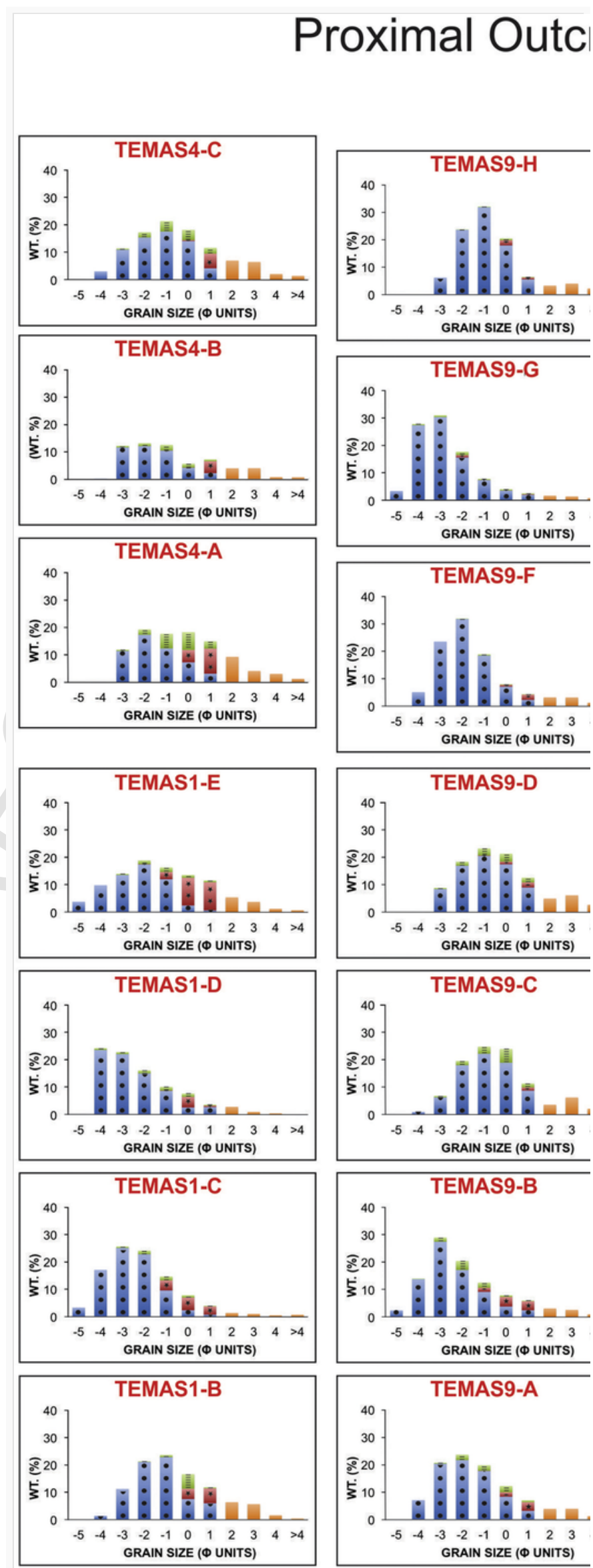



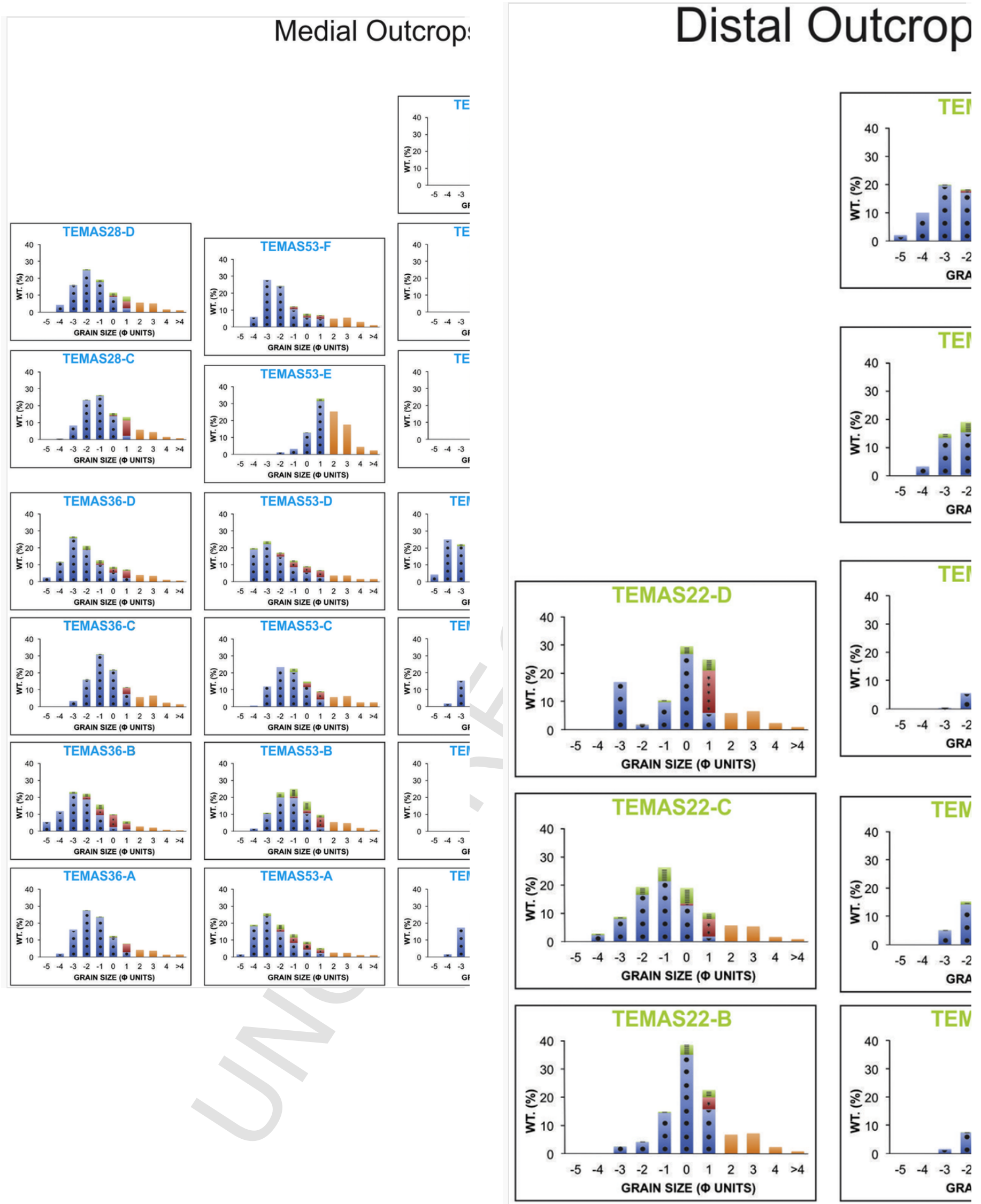
Supplementary Material 1. Component analysis of the most representative samples from the SMP Unit.
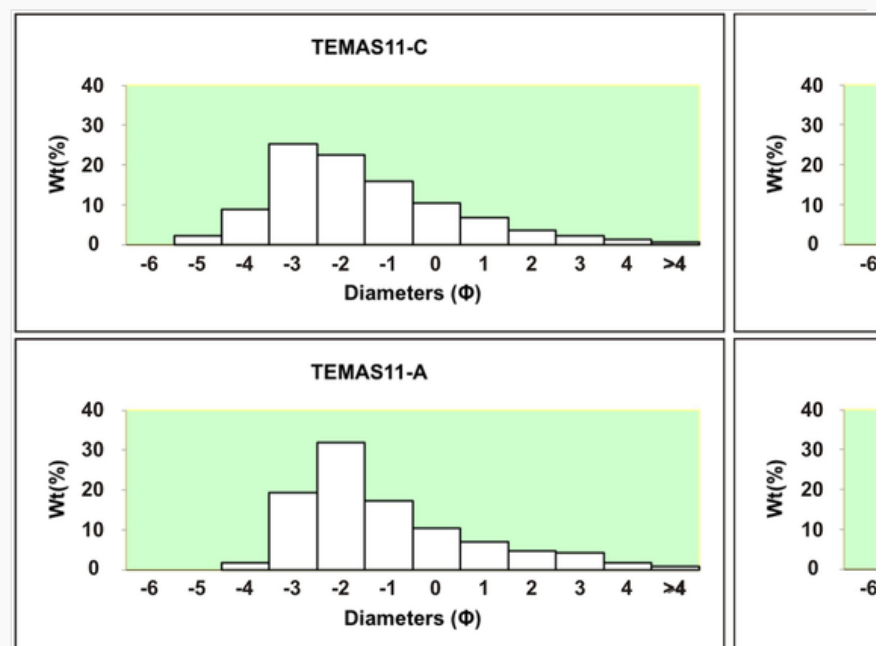

$\underset{\left.\stackrel{5}{5} \begin{array}{c}40 \\ 30 \\ 10 \\ 0\end{array}\right]}{-6}$

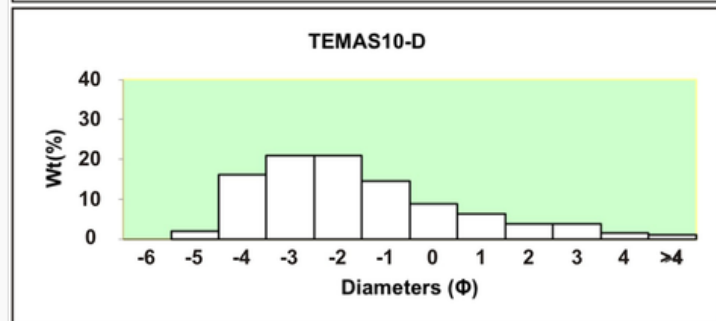

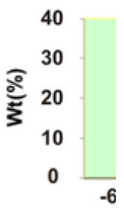
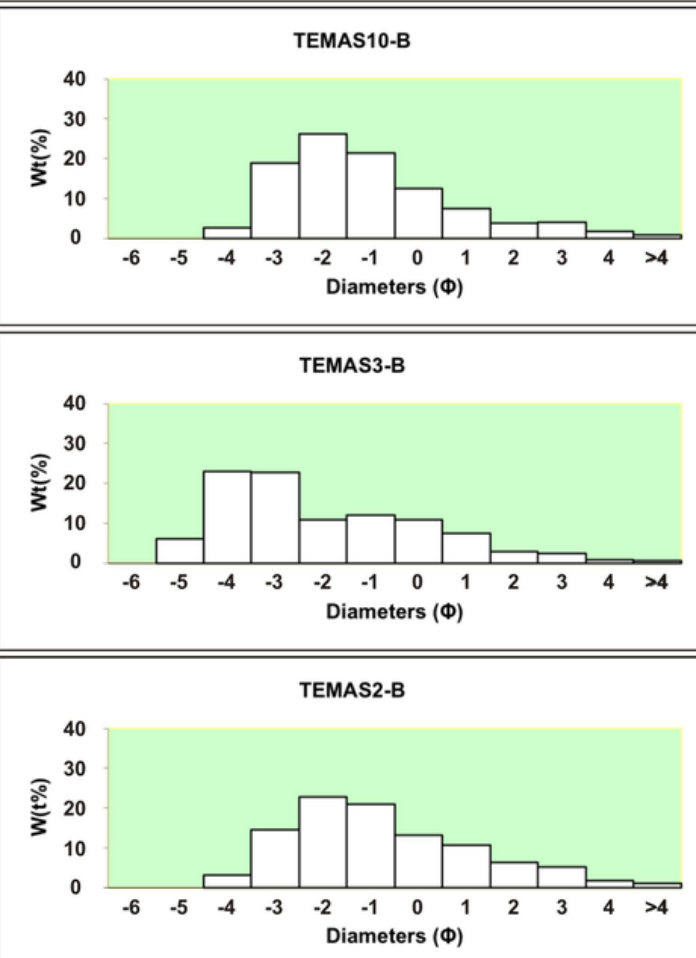

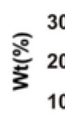

10

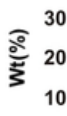

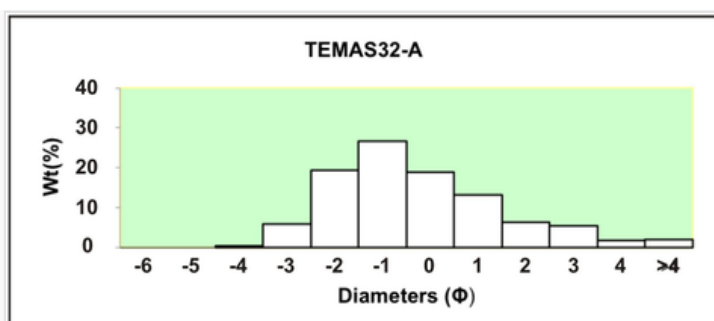

$\left.\underset{\text { ङ }}{3} \begin{array}{c}40 \\ 20 \\ 10 \\ 0\end{array}\right]$

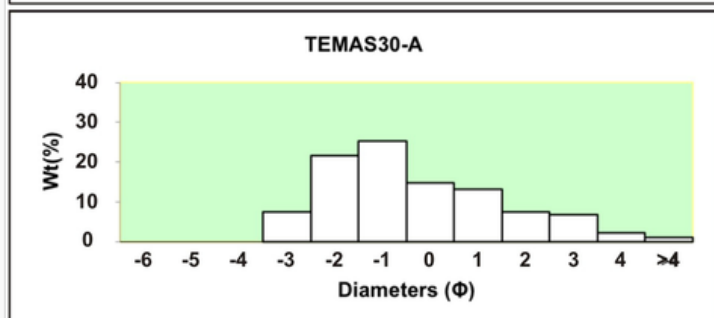

$\left.\underset{3}{3} \begin{array}{c}40 \\ 30 \\ 20 \\ 10 \\ 0\end{array}\right]$

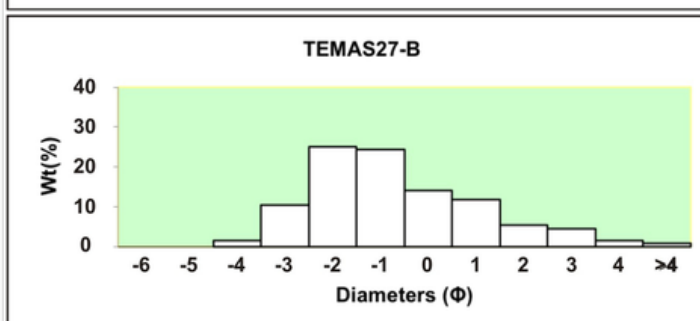

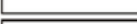

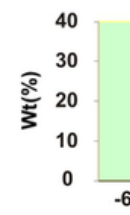

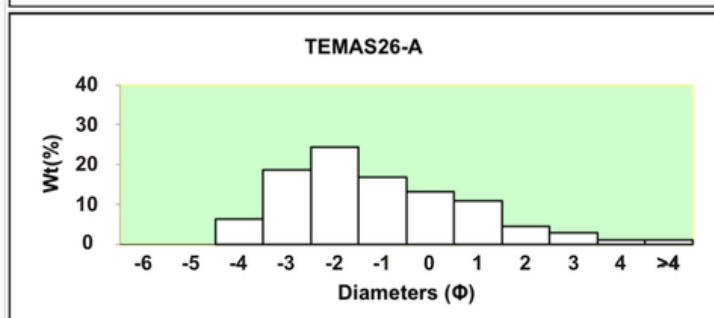

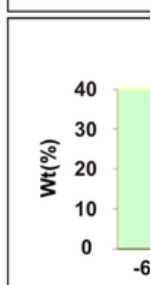

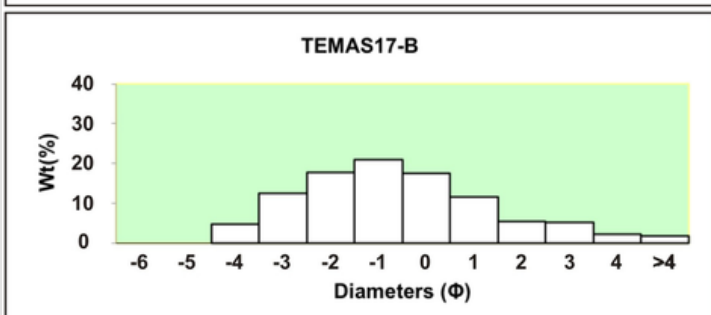

$\overline{(20}$

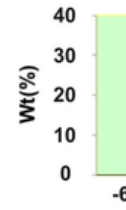

TEMAS16-B

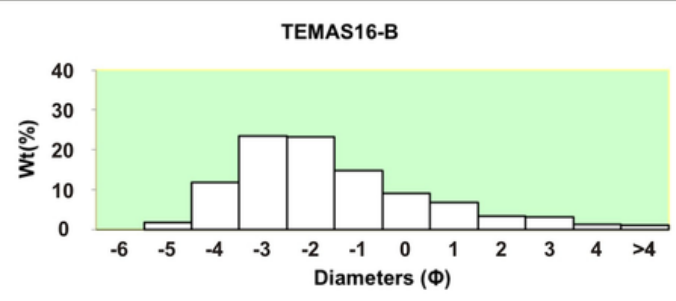




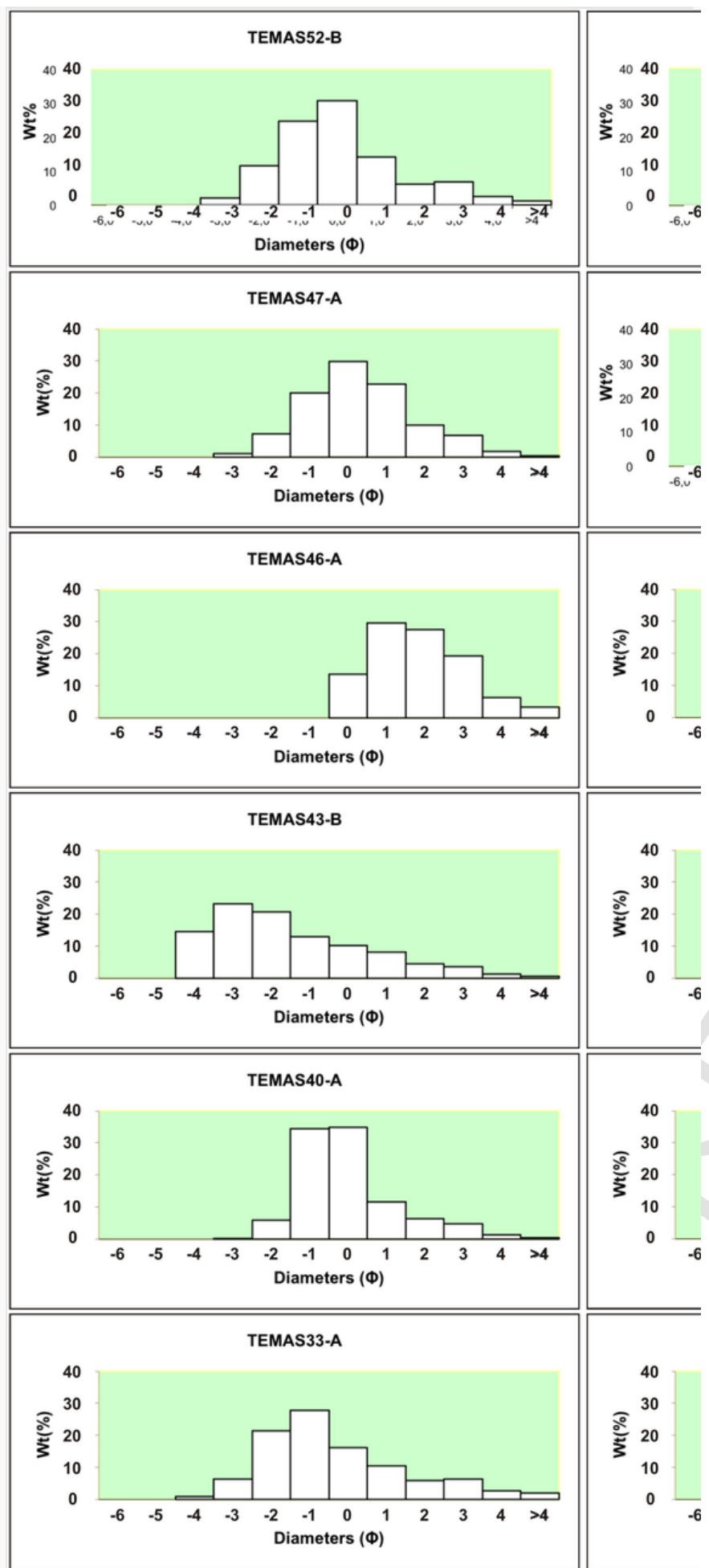

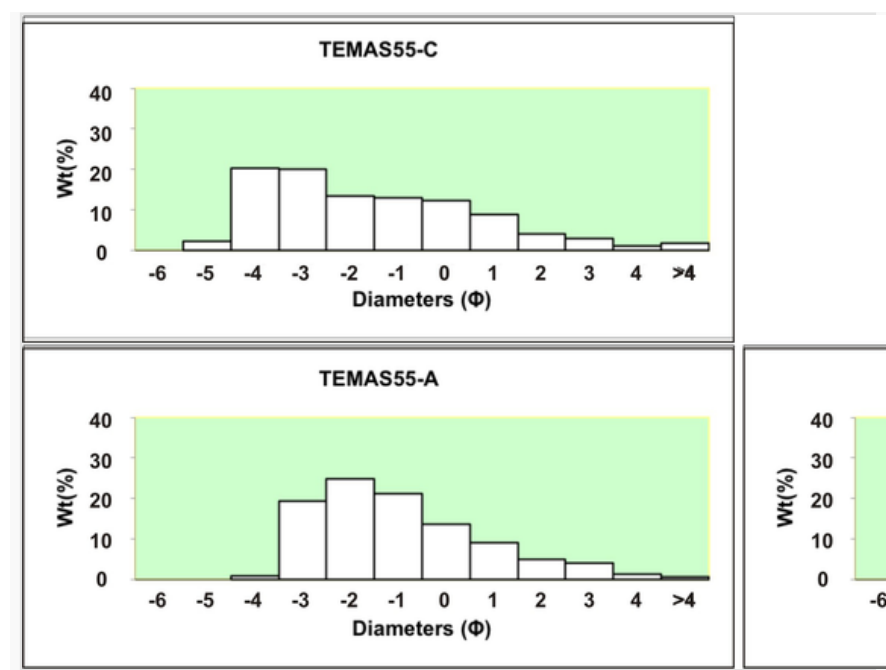

Supplementary Material 2. Granulometric histograms of samples from outcrops ofTable 1. 